\title{
Simultaneous gene expression and multi- gene silencing in Zea mays using maize dwarf mosaic virus
}

\author{
Wenshuang Xie ${ }^{1 \dagger}$, Dee Marie Marty ${ }^{2 \dagger}$, Junhuan $\mathrm{Xu}^{1}$, Nitika Khatri ${ }^{1}$, Kristen Willie ${ }^{2}$, Wanderson Bucker Moraes ${ }^{1}$ and \\ Lucy R. Stewart ${ }^{2^{*}}$ (iD
}

\begin{abstract}
Background: Maize dwarf mosaic virus (MDMV), a member of the genus Potyvirus, infects maize and is nonpersistently transmitted by aphids. Several plant viruses have been developed as tools for gene expression and gene silencing in plants. The capacity of MDMV for both gene expression and gene silencing were examined.

Results: Infectious clones of an Ohio isolate of MDMV, MDMV OH5, were obtained, and engineered for gene expression only, and for simultaneous marker gene expression and virus-induced gene silencing (VIGS) of three endogenous maize target genes. Single gene expression in single insertion constructs and simultaneous expression of green fluorescent protein (GFP) and silencing of three maize genes in a double insertion construct was demonstrated. Constructs with GFP inserted in the N-terminus of HCPro were more stable than those with insertion at the N-terminus of CP in our study. Unexpectedly, the construct with two insertion sites also retained insertions at a higher rate than single-insertion constructs. Engineered MDMV expression and VIGS constructs were transmissible by aphids (Rhopalosiphum padi).
\end{abstract}

Conclusions: These results demonstrate that MDMV-based vector can be used as a tool for simultaneous gene expression and multi-gene silencing in maize.

Keywords: Gene expression, Multigene silencing, Photobleaching, Potyvirus, Vascular puncture inoculation (VPI), Virus-induced gene silencing (VIGS)

\section{Background}

Maize (Zea mays) is one of the most widely planted crops in the world, used for human consumption, animal feed, and as raw material for biofuels and other products (reviewed in [1]). In addition to its agricultural importance, maize is a model plant for monocot crop genetics, with complete genome sequences of B73 [2] and 34 other maize genomes deposited in Maize Genetics and Genomics Database (maizeGDB.org). However, few

\footnotetext{
* Correspondence: lucy.stewart@usda.gov

tWenshuang Xie and Dee Marie Marty contributed equally to this work

USDA-ARS Corn Soybean and Wheat Quality Research Unit, Wooster, OH 44691, USA

Full list of author information is available at the end of the article
}

genomic tools for phenotyping impacts of individual genes are available. Maize transformation is technically difficult, expensive, and time consuming (reviewed in [3]). Thus, alternatives to transformation of stable transgenics are valuable. Virus-based tools developed for high-throughput virus-induced gene silencing (VIGS) could help fill the gap for maize gene function studies.

Many plant viruses have been developed as beneficial tools for expression of protein or VIGS (reviewed in [410]). VIGS has been used for gene functional analyses in host plants [11-14], utilizing target gene fragments in viral vectors in sense or antisense orientations or hairpin structures (see examples in [15]), with insertion

C C The Author(s). 2021 Open Access This article is licensed under a Creative Commons Attribution 4.0 International License, which permits use, sharing, adaptation, distribution and reproduction in any medium or format, as long as you give appropriate credit to the original author(s) and the source, provide a link to the Creative Commons licence, and indicate if changes were made. The images or other third party material in this article are included in the article's Creative Commons licence, unless indicated otherwise in a credit line to the material. If material is not included in the article's Creative Commons licence and your intended use is not permitted by statutory regulation or exceeds the permitted use, you will need to obtain permission directly from the copyright holder. To view a copy of this licence, visit http://creativecommons.org/licenses/by/4.0/ The Creative Commons Public Domain Dedication waiver (http://creativecommons.org/publicdomain/zero/1.0/) applies to the data made available in this article, unless otherwise stated in a credit line to the data. 
sequence fragments as small as 100-300 nt being effective to silence target genes [13]. Plant viruses have also been widely used for protein expression in many different plant species (reviewed in [5, 16-18]). In one case, a plant virus vector derived from bean pod mottle virus (BPMV) was even developed for simultaneous single gene expression and single gene silencing [19]. For maize, several viruses have been developed as tools for gene expression or silencing, including brome mosaic virus (BMV) [20,21], cucumber mosaic virus (CMV) [13], and maize rayado fino virus (MRFV) [22] for gene silencing [23], wheat streak mosaic virus (WSMV) [24-26] and sugarcane mosaic virus [27] for protein expression, foxtail mosaic virus (FoMV) for gene silencing [28] or protein expression [29] and guide RNA delivery for CRISPR/ Cas9 gene editing [30], barley stripe mosaic virus for gene silencing [23] or protein expression [31] or for guide RNA delivery [32] and barley yellow striate mosaic virus (BYSMV) for simultaneous guide RNA and high cargo-capacity protein expression [33].

Viruses in the family Potyviridae, or potyviruses, have been developed as heterologous gene expression vectors in various plant hosts, enabling tracking of virus movement and other experiments. Viruses in the family Potyviridae have flexuous, rod-shaped virus particles with a single-stranded positive-sense RNA genome encapsidated by viral coat protein, and are the largest group of plant viruses (reviewed in [34]). The potyvirus genome encodes a polyprotein which is cleaved by its own viral proteases to produce 10 mature functional viral proteins for virus replication, pathogenicity, aphid transmission and other functions through interaction with many plant host proteins (reviewed in [34]). Potyviruses developed for protein expression include tobacco etch virus (TEV) [35, 36], zucchini yellow mosaic virus (ZYMV) [37], plum pox virus (PPV) [38], potato virus A (PVA) [3941], turnip mosaic virus (TuMV) [42, 43], tobacco vein banding mosaic virus (TVBMV) [44], WSMV [24], and SCMV [27]. Because of their strong silencing suppressor, potyviruses were not favored for development of VIGS vectors, however, PVA was developed for transient gene silencing [45]. The most common insertion sites in these potyvirus-based vectors are the P1/HCPro and NIb/CP coding sequence junctions, with four other junction sites in the polyprotein open reading frame (ORF) or at the $5^{\prime}$ end of the polyprotein ORF utilized in some vectors.

Since more than one sequence insertion site can be utilized for some potyviruses, and their expandable rodshaped virions are generally more tolerant of insertion sequences than viruses with icosahedral virions and inherent packaging constraints, expression of two to five proteins from a single vector has been achieved in some of these systems [36, 41-43].
Given the features of potyviruses and interest in further tools for maize, maize dwarf mosaic virus (MDMV) was an attractive option for development. MDMV was first reported in Ohio in 1963 [46]. MDMV is naturally transmitted by aphids in a nonpersistent manner [47], and is readily transmissible by rub inoculation in the laboratory [48]. MDMV infected plants have mosaic symptoms on leaves of susceptible cultivars of maize that can be visible as early as 5-7 days after rub inoculation. MDMV is common in the United States and is capable of reducing yields, but successful resistance breeding and disease management have limited major yield loss (reviewed in [49]). In addition to maize, the host range of MDMV includes some sorghum cultivars and Johnsongrass (Sorghum halepense L.), which is a major overwintering virus reservoir [50, 51]. Nearcomplete consensus sequence of a lab-maintained isolate MDMV OH2 (GenBank accession no. JQ403609) and complete sequence of a derived infectious clone (MDMV OH1; GenBank accession no. JQ403608) from Ohio were previously reported [52]. Here we report the cloning and sequencing of a new Ohio MDMV isolate from Johnsongrass, MDMV OH5, development of MDMV $\mathrm{OH} 5$ infectious clones, and engineered constructs for simultaneous gene expression and multi-gene silencing in maize. We report the first development of a virusbased vector for simultaneous gene expression and multi-target VIGS in maize.

\section{Results}

Complete sequence of MDMV OH5 and developing a fulllength infectious clone

MDMV infection of Ohio-collected Johnsongrass ( $S$. halepense L.) was confirmed by RT-PCR using previously published MDMV OH-specific primers to NIb (MDMV-7065F) and the 3'UTR (MDMV GenR1, [52], Additional file 1: Table S1), and by sequencing the amplified fragments. Typical mosaic symptoms developed when Johnsongrass leaf sap was rub-inoculated onto susceptible 'Silver Queen', 'Early Sunglow', and 'Oh28' maize plants (data not shown). RNA from original collected Johnsongrass leaves was used for cDNA synthesis, cloning and sequencing. The complete sequence of the MDMV isolate was determined by Sanger sequencing of amplicons, including $5^{\prime}$ and $3^{\prime}$ rapid amplification of cDNA ends amplicons (RACE; primers in Additional file 1: Table S1).

The precise $5^{\prime}$ sequence expressed from a cloned cDNA platform, and whether it is authentic, may be important or even essential in infectivity of the derived clones (see [53] and references therein). Thus, we experimentally determined the MDMV OH5 authentic 5' most nucleotide using $5^{\prime}$-RACE as one of the first steps to generate optimal clones. The $5^{\prime}$-most nucleotide of 
MDMV OH5, identified by Sanger sequence of $5^{\prime}$ RACE amplicons, was adenosine, the same as for other published MDMV isolates: MDMV Bulgaria (GenBank accession no. NC_003377, [54], MDMV Golestan (GenBank accession no. JQ280313.1), MDMV Sz0605 (GenBank accession no. FM883211.2 [55], MDMV Mv0801 (GenBank accession no. FM883164.2 [55] (Table 1). RACE was also performed for MDMV-Italy (GenBank accession no. JX185302) and MDMV OH2, for which GenBank sequences were missing $5^{\prime}$-most sequences. This sequencing identified seven $5^{\prime}$ nucleotides for MDMV OH2 (5'-AAAAACA-3') missing in the nearcomplete sequence submission and $355^{\prime}$ nucleotides missing in the near-complete sequence submission of MDMV Italy (5'-AAAAACAACAAGACTCAACACA ACACAACCAAACA-3'). GenBank sequence submissions of near-complete sequences of these viruses were updated and completed with the $5^{\prime}$ sequence data for these viruses. Based on RACE data, all isolates had a 5'most adenosine residue, rather than $5^{\prime}$-most guanine of the cloned virus MDMV OH1 (GenBank accession no. JQ403608), for which 5'- RACE on the MDMV OH2 source virus had not been successfully conducted [52]. All three MDMV OH sequences (MDMV OH1, MDMV $\mathrm{OH} 2$ and MDMV OH5) had the same $3{ }^{\prime}$-end sequences as determined by $3^{\prime}$ - RACE (Table 1 ). The complete sequence of MDMV OH5 was $9538 \mathrm{nt}$ compared to the 9442 nt MDMV OH2 RACE-completed sequence, and shared $89 \%$ nucleotide and $96 \%$ polyprotein amino acid sequence identity with MDMV OH2. An additional 96 nucleotides present in MDMV OH5 were located in frame in the coding region for the $\mathrm{N}$-terminus of the MDMV coat protein $(\mathrm{CP})$ gene, such that MDMV OH5 is predicted to encode a coat protein containing 32 additional amino acids and with a predicted molecular weight of $34 \mathrm{kDa}$, compared to the $30 \mathrm{kDa} C P$ predicted for MDMV OH1 and $\mathrm{OH} 2$. This additional sequence at the $\mathrm{N}$-terminal $\mathrm{CP}$ coding sequence was previously found for all Ohio field isolates of MDMV in a survey of maize and Johnsongrass [56], suggesting that laboratory mechanically-passaged isolate (MDMV OH2) collected in Ohio ca. 1970 and the derived clone (MDMV OH1) may have lost $\mathrm{N}$-terminal coat protein encoding sequence in passaging [56]. The complete sequence of the cloned Johnsongrassderived field MDMV isolate was named MDMV OH5 and deposited as GenBank accession no. MN615724.
Full-length MDMV OH5 sequence was cloned into binary vector pJL89 [57] and named pWX6 (Fig. 1a). To examine infectivity of pWX6, in vitro RNA transcript derived from pWX6 was inoculated into 'Silver Queen' maize by vascular puncture inoculation (VPI [58, 59]) using amplified full-length sequences with primer-added T7 promoter to generate transcripts as was previously successful for the reported MDMV OH1 infectious clone [52]. Typical mosaic symptoms were observed in a subset of plants after inoculation (Fig. 2g), indicating that clone pWX6 is infectious with an infection rate of 33\% by VPI (Table 2), an improvement over the ca. 10\% maximum infection rates originally reported for the MDMV $\mathrm{OH} 1$ infectious clone [52]. Infection rates using this methodology were also improved for the original MDMV OH1 clone (57\%), indicating that improvement was attributable to the modified inoculum preparation protocol (full-length sequence amplification and/or in vitro transcription, VPI procedure remained unchanged) rather than inherently higher infectivity of the MDMV OH5 pWX6 clone. Initial experiments to launch virus infection from the binary vector clones by agroinfiltration of maize or Nicotiana benthamiana from this construct were unsuccessful (data not shown), and further clones were tested using only the successful maize VPI approach.

\section{Expression of GFP from gene insertion at $\mathrm{Nlb} / \mathrm{CP}$ junction in pWX27}

To explore whether MDMV OH5 could be used for gene expression, the green fluorescent protein (GFP) gene was assembled in-frame within the polyprotein between nuclear inclusion b-RNA-dependent RNA polymerase (NIb-RdRP) and $\mathrm{CP}$ genes of MDMV OH5 in clone pWX6 to create pWX27 (Fig. 1b). NIb/CP cleavage sequence (EVIDVKHQAGE) was duplicated upstream and downstream of the inserted GFP sequence, with degenerate coding sequences to avoid direct sequence duplication, in order to allow efficient GFP cleavage from encoded polyprotein. Clone pWX27 was confirmed to be infectious with an average infection rate of $37 \%$ by VPI (Table 2), and typical mosaic symptoms developed in infected plants. GFP expression was visualized under a fluorescent microscope, indicating that MDMV OH5 could be used as a gene expression vector (Fig. 2a). Western blots for GFP showed that the amount

Table 1 5'- and 3'-RACE of MDMV isolate genomic RNA

\begin{tabular}{llll}
\hline Virus isolate & GenBank accession no. & 5' RACE $\mathbf{5}$ ' - $\mathbf{3}$ sequence & 3' RACE 5' - $\mathbf{s e q u e n c e}$ \\
\hline MDMV OH2 & JQ403609.1 & AAAAACAACAAGACT & TTCGTGGTGAGAGAC \\
MDMV It & JX185302.1 & AAAAACAACAAGACT & TTCGTGGTGAGAGAC \\
MDMV OH5 & MN615724 & AAAAACAACAAGACT & TTCGTGGTGAGAGAC \\
\hline
\end{tabular}



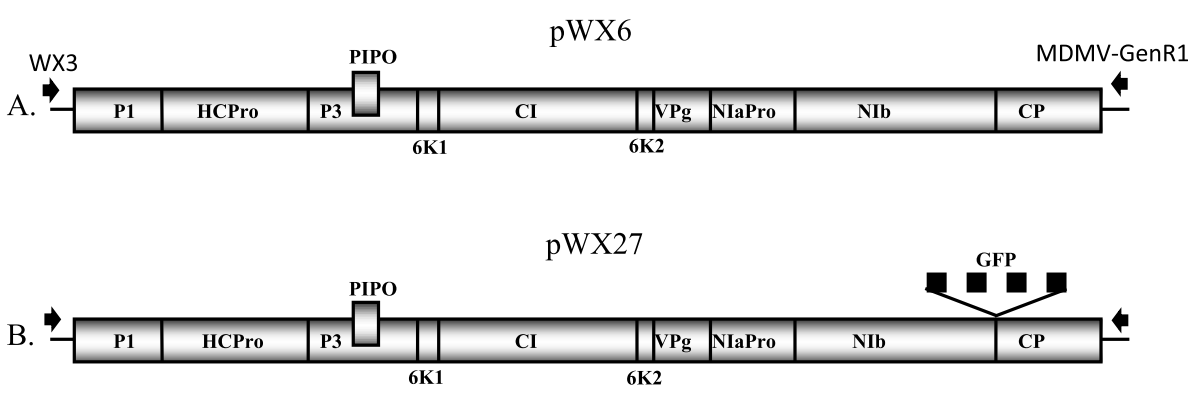

pWX68
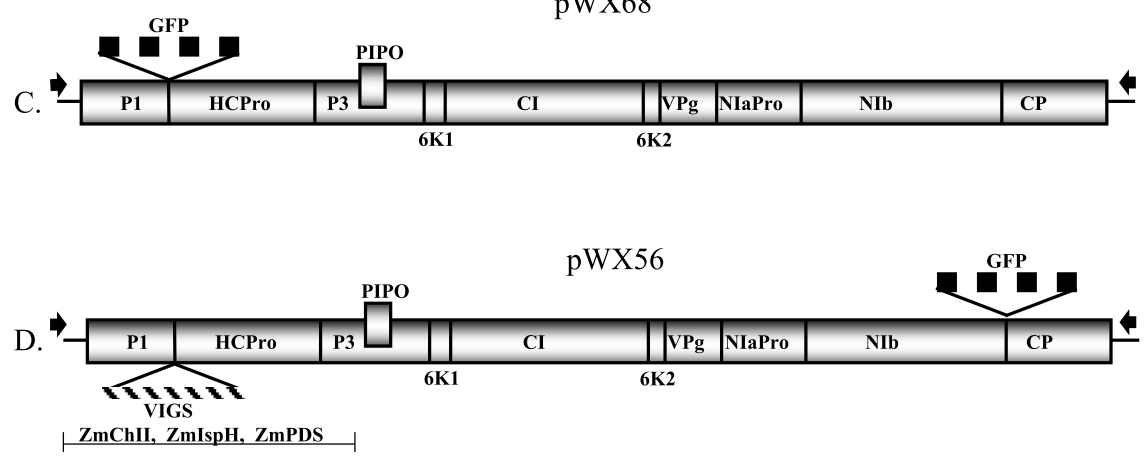

Fig. 1 Genome layout of MDMV OH5 full-length infectious clone constructs. a. pWX6 (14,229 bp), infectious wild-type clone. b. pWX27 (15,009 bp), GFP gene inserted in-frame between NIb and CP coding sequences. c. pWX68 (15,018 bp), GFP gene inserted in-frame between P1 and HCPro coding sequences. d. pWX56 VIGS (15,798 bp), GFP gene inserted in-frame between Nlb and CP coding sequences; and 249 bp each from

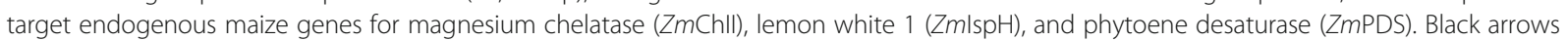
indicate location of $5^{\prime}$ WX3 and 3' MDMV-GenR1 primers (Table S1) used for amplification prior to in vitro transcription. RNA transcripts were synthesized from amplicon with primer-added 5' T7 promoter sequence. P1 = protein 1 protease, HCPro = helper component protease, $\mathrm{P} 3=$ protein 3 protease. $\mathrm{PIPO}=$ pretty interesting Potyviridae open reading frame. $6 \mathrm{k}_{1}=6 \mathrm{kD}$ protein $1 . \mathrm{Cl}=$ cylindrical inclusions. $6 \mathrm{k}_{2}=6 \mathrm{kD}$ protein 2 . $\mathrm{VPg}=$ viral protein genome linked. Nla-Pro $=$ nuclear inclusion a-protease. NIb- RdRP = nuclear inclusion b-RNA dependent RNA polymerase. $\mathrm{CP}=$ coat protein

of expressed GFP detected (expected size $29.4 \mathrm{kDa}$ ) declined slightly at weeks two and three compared to week one (Fig. 3; raw images shown in Additional file 3).

\section{Expression GFP from gene insertion at $\mathrm{P} 1 / \mathrm{HCPro}$ junction in pWX68}

We next inserted GFP between P1 and HCPro coding sequence in-frame within the polyprotein to create clone pWX68 (Fig. 1c). Clone pWX68 infectivity was confirmed by VPI with average infection rate of $43 \%$ (Table 2). Typical mosaic symptoms were observed, and GFP expression was visualized (Fig. 2b). Western blot analysis of pWX68-infected leaves also showed GFP expression (Fig. 3; raw images shown in Additional file 3).

\section{Simultaneous silencing of three genes and heterologous GFP expression from pWX56}

Since GFP expression from gene insertion at each of two sites was successful, we next examined whether MDMV $\mathrm{OH} 5$ could be used for simultaneous gene silencing and gene expression using both insertion sites in a single construct. Using similar insertion sizes for VIGS, we aimed to target multiple genes in one insertion site. A triple gene-targeting VIGS insertion, ZmChlI-IspH-PDS, was created to silence magnesium chelatase, lemon white 1 and phytoene desaturase genes, with 249 nt sequence from each targeted maize gene for a $747 \mathrm{nt}$ total construct size. This triple-gene VIGS construct was inserted in-frame within the polyprotein between P1 and HCPro with inserted NIb cleavage site sequence of MDMV OH5 into a pWX27 backbone to create pWX56 (Fig. 1d). The infectivity of clone pWX56 was confirmed by VPI of RNA transcripts, with an average infection rate of $22 \%$ (Table 2).

Green fluorescence was visualized in infected plants (Fig. 2a-d), and GFP protein expression confirmed by Western blot analyses (Fig. 3). Strong photobleaching was also observed in all leaves and stem tissue (Fig. 2FG, Fig. S1D) and tassels (data not shown). Silencing was not tested in root or other tissues. Retention of GFP coding sequences and sequences of each component of the triple VIGS insertion were verified by RT-PCR analysis (Additional file 2: Fig. S1A). Decreased levels of chlorophyll were measured compared to plants inoculated with 


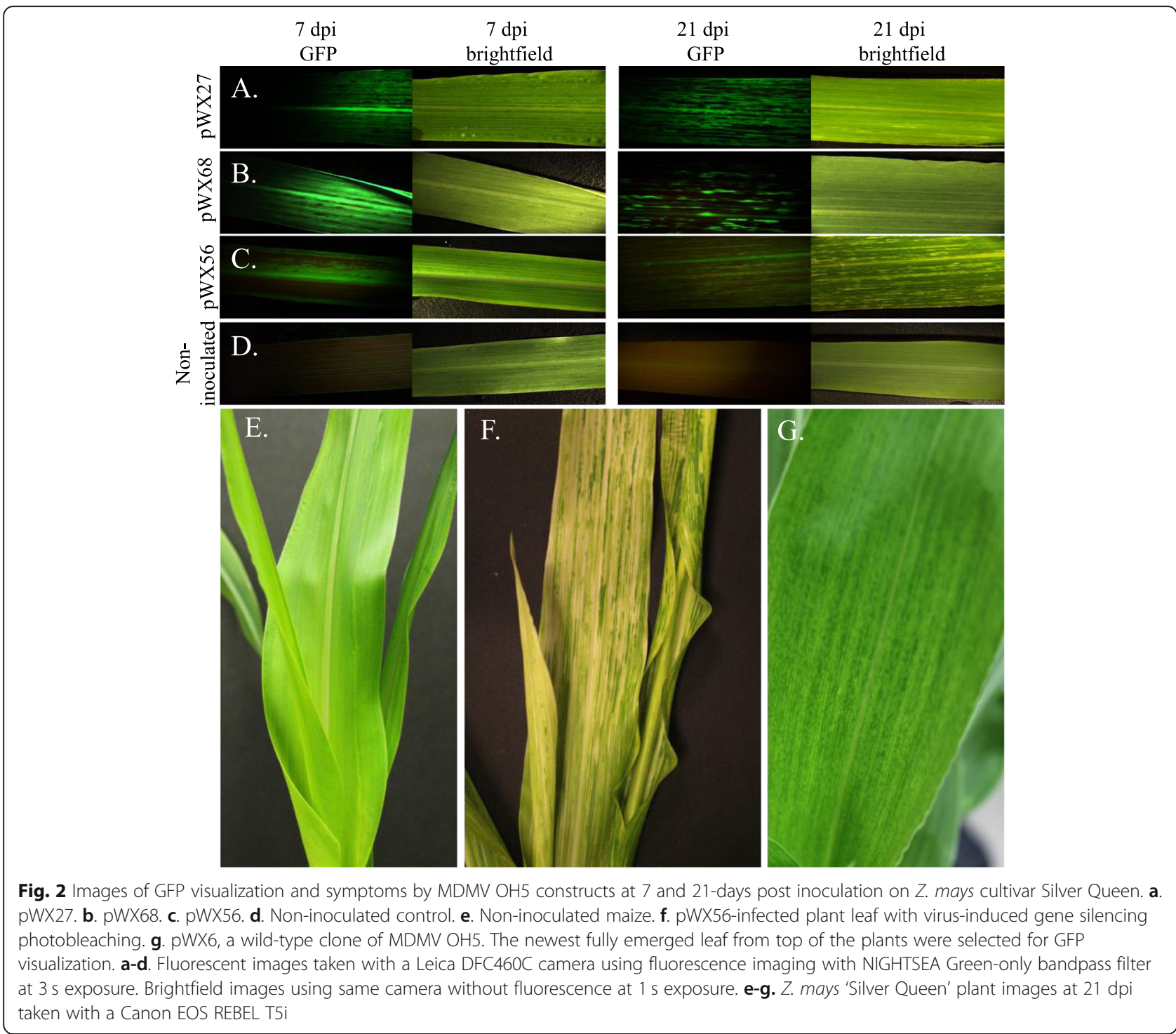

Table 2 Efficiency of vascular puncture inoculation infection of MDMV OH5 derived constructs

\begin{tabular}{|c|c|c|c|c|c|c|c|c|c|c|}
\hline & Rep 1 & Rep 2 & Rep 3 & Rep 4 & Rep 5 & Rep 6 & Rep 7 & Rep 8 & Rep 9 & Total \\
\hline Clone & $\begin{array}{l}\text { Infected/ } \\
\text { Inoculated }\end{array}$ & $\begin{array}{l}\text { Infected/ } \\
\text { Inoculated }\end{array}$ & $\begin{array}{l}\text { Infected/ } \\
\text { Inoculated }\end{array}$ & $\begin{array}{l}\text { Infected/ } \\
\text { Inoculated }\end{array}$ & $\begin{array}{l}\text { Infected/ } \\
\text { Inoculated }\end{array}$ & $\begin{array}{l}\text { Infected/ } \\
\text { Inoculated }\end{array}$ & $\begin{array}{l}\text { Infected/ } \\
\text { Inoculated }\end{array}$ & $\begin{array}{l}\text { Infected/ } \\
\text { Inoculated }\end{array}$ & $\begin{array}{l}\text { Infected/ } \\
\text { Inoculated }\end{array}$ & $\begin{array}{l}\text { Infected/ } \\
\text { Inoculated }\end{array}$ \\
\hline $\begin{array}{l}\text { MDMV } \\
\mathrm{OH}^{\mathrm{a}}\end{array}$ & $13 / 19$ & $5 / 9$ & $4 / 9$ & $1 / 10$ & $6 / 10$ & $8 / 8$ & $8 / 9$ & $4 / 10$ & $5 / 10$ & $54 / 94(57 \%)$ \\
\hline pWX6 & $4 / 8$ & $2 / 6$ & $1 / 7$ & $4 / 8$ & $2 / 6$ & $1 / 7$ & $N T^{b}$ & NT & NT & $14 / 42(33 \%)$ \\
\hline pWX27 & $5 / 18$ & $5 / 17$ & $11 / 20$ & NT & NT & NT & NT & NT & NT & $21 / 55(38 \%)$ \\
\hline pWX68 & $14 / 39$ & $18 / 31$ & $12 / 34$ & NT & NT & NT & NT & NT & NT & $\begin{array}{l}44 / 104 \\
(42 \%)\end{array}$ \\
\hline pWX56 & $5 / 16$ & $5 / 24$ & $4 / 26$ & NT & NT & NT & NT & NT & NT & $14 / 66$ (21\%) \\
\hline
\end{tabular}

${ }^{a}$ Infectious clone reported in [52]

${ }^{b}$ Not tested 


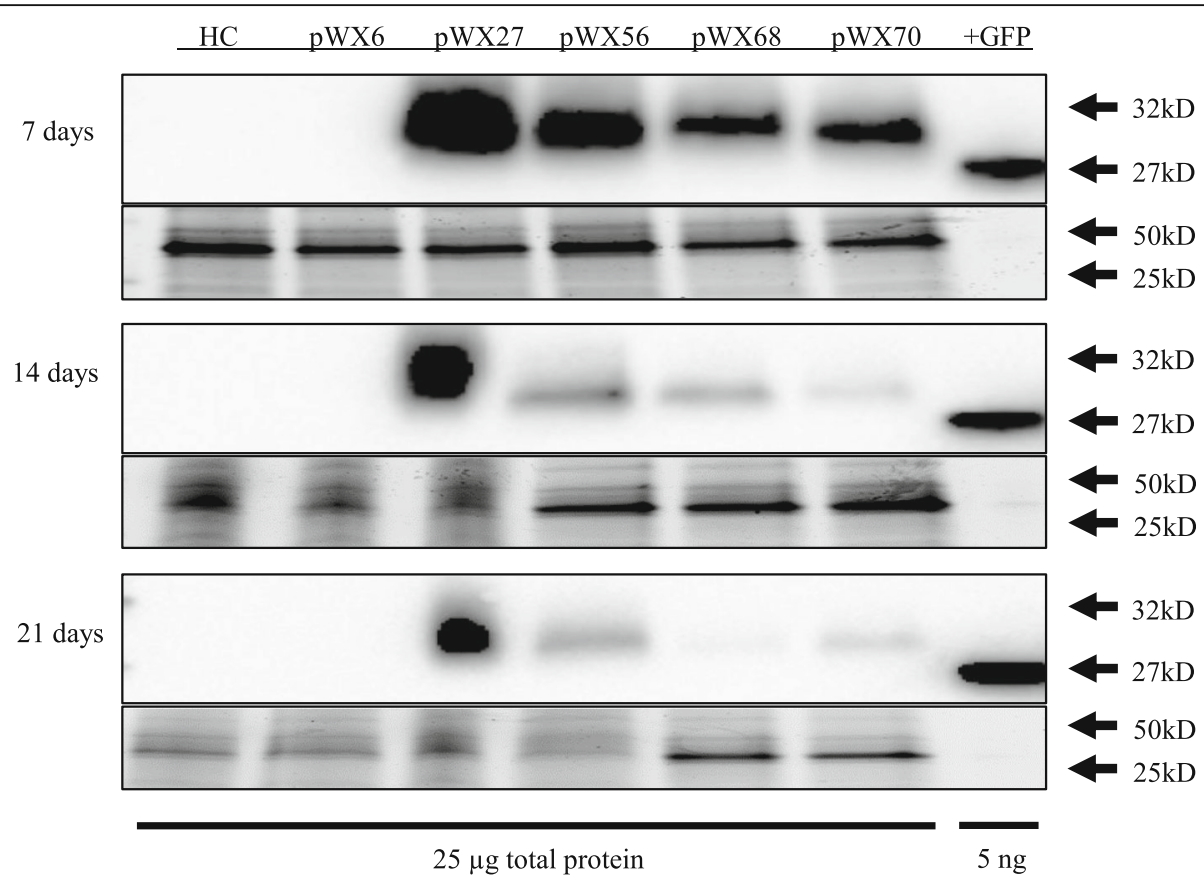

Fig. 3 Western blot analysis of GFP in MDMV OH5 derived constructs. Samples of the newest fully emerged leaf from top of the plants were collected at 7, 14, and 21 days post rub-inoculation and analyzed for GFP protein using Anti-GFP antibody (Abcam, USA). Constructs were as diagrammed in Fig. 1, and pWX70 is similar to pWX56 with a similar-sized insert at P1/HCPro without further data reported. GFP from MDMV OH5 constructs with additional 6 xHis and protease cleavage sequences with predicted molecular weight of $29.4 \mathrm{kDa}$ were detected at slightly slower migration (32 kDa estimated based on ladder) compared to the positive control GFP (27 kDa estimated based on ladder) with predicted amino acid molecular weight of $26.8 \mathrm{kDa}$. Twenty-five $\mu \mathrm{g}$ total protein was loaded per sample and $5 \mathrm{ng}$ recombinant E. coli GFP protein (Abcam, ab119740) was loaded as the positive control. Coomassie-stained gel loading control for each time point are shown in lower panels. Imaging of proteins was done on a Bio-Rad Imaging System utilizing Bio-Rad's Stain Free Technology. Raw gel and blot images included in Additional file 3

the wild type clone pWX6 or healthy control plants (Additional file 2: Fig. S1B). Quantitative RT-PCR (RTqPCR) was used to examine individual target gene transcript reduction of pWX56. All three genes targets, $Z m C h l I, Z m P D S$ and $Z m I s p H$, had reduced RNA transcript levels compared to wild type pWX6 infected plant controls at 14 days post inoculation (Fig. 4).

\section{Differential stability of constructs}

One of the ubiquitous challenges of plant virus-based expression and VIGS vectors is instability of the heterologous sequence and loss of insertion sequences over time during replication cycles of the virus. Stability of the heterologous sequence insertions in pWX27, pWX68, and pWX56 was assayed over three weeks after rub-inoculation of 10-day-old seedlings using VPI launched infected leaf materials of pWX6, pWX27, pWX68, and pWX56 stored in a $-80{ }^{\circ} \mathrm{C}$ freezer. At each time point, the youngest fully emerged leaf from the top of each plant was assayed for virus and insert stability by RT-PCR analysis with primers flanking the insertion sites (Additional file 1: Table S1). Amplicons were scored as full length insert band only a; full length insert plus smaller bands detected $\mathbf{b}$; multiple bands with no full length insert detected $\mathbf{c}$; single band of less than fulllength insert, with size usually near that of wild type virus amplicon $\mathbf{d}$; and no band $\mathbf{e}$ (Table 3, Fig. 5c; Additional file 2: Fig. S2; raw images in Additional file 3). pWX27 showed rapid loss of insertion sequence, with no samples showing full-length insert only by $14 \mathrm{dpi}$. pWX27 amplicons detected shifted from predominantly full-length or a mixture of amplicons with full-length insert to loss of most full length insert detection by $21 \mathrm{dpi}$ (Table 3). In contrast, pWX68 retained some full-length only insert by 14 and $21 \mathrm{dpi}$. Even less full-length only insertion loss was observed for pWX56 VIGS and GFP insertion sequences (Table 3). Statistical comparison of the single band categories a (full-length insert single band) and $\mathbf{d}$ (single smaller than full-length band/near wild-type reversion) across insertion sites for the various constructs supported significantly improved insert stability of both pWX56 insertions compared to pWX27 and pWX68 insertions (Fig. 5a, b; see Additional file 1: Tables S2-S4 for $P$-values), indicating that dual insertion stabilizes the construct. Both GFP and triple VIGS insert stability in pWX56 were also examined through series of 


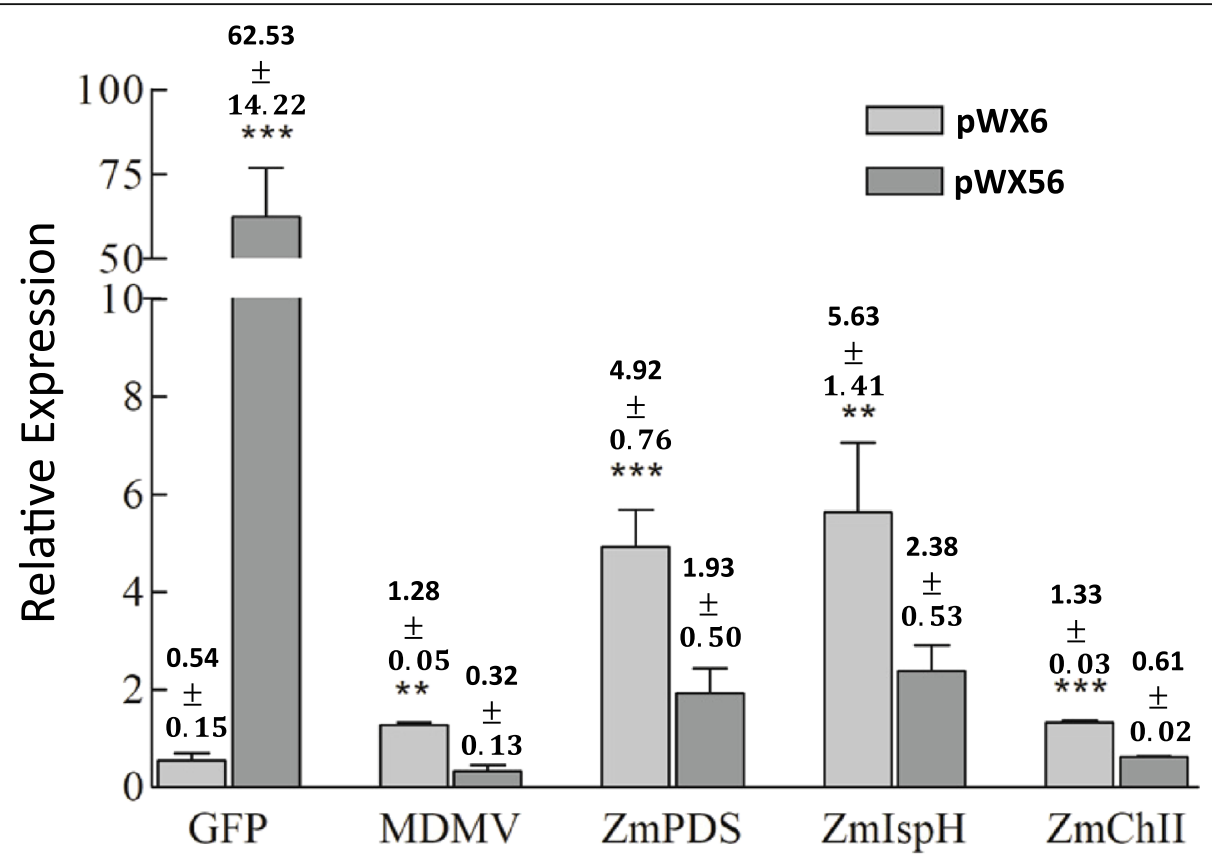

Fig. 4 Mean target gene transcript relative expression ratios of 14 dpi of pWX56 inoculation. Mean values were derived from three samples of the newest fully emerged leaf of plants inoculated with wild type cloned virus (pWX6), and 6 samples of pWX56-infected plants. Folypolyglutamate synthase (FPGS) reference gene was used for all calculations (primers Table S1). Error bars represent standard error. Bars headed by asterisk * are significantly different with $p$-values $<=0.05\left({ }^{*}\right), 0.01\left(^{* *}\right)$ and $0.001\left(^{* *}\right)$. Student's T-test was used

five passages to 10 plants by rub inoculation. GFP expression and VIGS photobleaching were detected in all five passages but were weak by the fifth passage (Additional file 1: Table S5; Additional file 2: Fig. S1).

\section{Aphid transmission of pWX56}

Aphids (Rhopalosiphum padi) from both Ohio- and Kansas- originating colonies were used to test transmission of pWX56. Aphid transmission was successful as indicated by typical mosaic symptoms for both the wild type pWX6 cloned virus and pWX56, with no statistically significant difference in transmission rates for each construct or for $R$. padi colonies from Kansas versus Ohio. (Fig. 6). In pWX56 aphid-inoculated plants, photobleaching was observed (Additional file 2: Fig. S3A) and GFP expression was visualized by fluorescence microscopy (data not shown). VIGS and GFP insertions were further confirmed by RT-PCR detection of target genes (Additional file 2: Fig. S3B). VIGS insert sequence remained intact at 17 days post aphid inoculation, while GFP insert sequence showed a mix of intact and partially intact sequences at 17 days post aphid inoculation. Each of the two $R$. padi populations transmitted pWX6 and pWX56 at similar rates of 45-90\% (9-18 infected plants per 20 plants infested by aphids with no statistically significant difference $(P>0.05)$ (Fig. 6).

\section{Discussion}

We have demonstrated that MDMV can be used for simultaneous gene expression and multi-gene silencing in maize, the first pairing of both of these capabilities in a single virus-based tool for maize. This is significant as more than one gene could be evaluated simultaneously, with opposite overexpression and knockdown expression if desired, for functional analyses. This opens up the possibility of modifying other agriculturally important potyviruses/crops for gene expression and function studies. Unexpectedly, dual insertion also increased the stability of heterologous sequences in the virus compared to single site insertion constructs. As yet, the mechanism underlying the stabilization effect for dual insertion in this construct is not known. Similarly, since this is one of only two reported potyviruses that have been developed for VIGS, whether the ability of MDMV to be modified for successful multi-target VIGS and concurrent gene expression is commonplace but simply untested for potyviruses, or is a unique result of some rare feature of this virus remains unknown. Nevertheless, insertion sequences can be cloned and efficiently expressed simultaneously in pWX56, and constructs can be launched by transcript VPI. VPI has an estimated tenfold greater efficiency than initial launching of transcript RNA by rub-inoculation to plant leaves [59]. Once the construct has infected plants, early collections of leaves 
Table 3 GFP and VIGS insert stability in constructs pWX27, pWX68, and pWX56

\begin{tabular}{|c|c|c|c|c|c|c|c|c|c|}
\hline Construct & Insert & Rep. $^{\text {a }}$ & Time (dpi) & Total plants & $a^{b}$ & b & c & d & e \\
\hline \multirow[t]{9}{*}{$\mathrm{pWX27}$} & GFP & 1 & 7 & 20 & 9 & 10 & 0 & 0 & 1 \\
\hline & & 2 & 7 & 20 & 6 & 13 & 1 & 0 & 0 \\
\hline & & 3 & 7 & 20 & 11 & 8 & 0 & 1 & 0 \\
\hline & & 1 & 14 & 20 & 0 & 18 & 2 & 0 & 0 \\
\hline & & 2 & 14 & 20 & 0 & 13 & 4 & 2 & 1 \\
\hline & & 3 & 14 & 20 & 0 & 16 & 4 & 0 & 0 \\
\hline & & 1 & 21 & 20 & 0 & 5 & 12 & 2 & 1 \\
\hline & & 2 & 21 & 20 & 0 & 3 & 9 & 8 & 0 \\
\hline & & 3 & 21 & 20 & 0 & 3 & 12 & 5 & 0 \\
\hline \multirow[t]{9}{*}{ pWX68 } & GFP & 1 & 7 & 20 & 14 & 4 & 2 & 0 & 0 \\
\hline & & 2 & 7 & 20 & 2 & 11 & 4 & 3 & 0 \\
\hline & & 3 & 7 & 20 & 3 & 10 & 5 & 2 & 0 \\
\hline & & 1 & 14 & 20 & 10 & 6 & 2 & 2 & 0 \\
\hline & & 2 & 14 & 20 & 3 & 6 & 5 & 5 & 1 \\
\hline & & 3 & 14 & 20 & 2 & 4 & 6 & 8 & 0 \\
\hline & & 1 & 21 & 20 & 3 & 9 & 4 & 3 & 1 \\
\hline & & 2 & 21 & 20 & 0 & 0 & 12 & 7 & 1 \\
\hline & & 3 & 21 & 20 & 0 & 2 & 7 & 9 & 2 \\
\hline \multirow[t]{9}{*}{ pWX56 } & GFP & 1 & 7 & 20 & 7 & 6 & 1 & 4 & 2 \\
\hline & & 2 & 7 & 20 & 11 & 4 & 0 & 3 & 2 \\
\hline & & 3 & 7 & 20 & 8 & 5 & 1 & 1 & 5 \\
\hline & & 1 & 14 & 20 & 9 & 7 & 2 & 2 & 0 \\
\hline & & 2 & 14 & 20 & 3 & 14 & 1 & 2 & 0 \\
\hline & & 3 & 14 & 20 & 8 & 7 & 3 & 0 & 2 \\
\hline & & 1 & 21 & 20 & 2 & 8 & 2 & 4 & 4 \\
\hline & & 2 & 21 & 20 & 5 & 10 & 0 & 4 & 1 \\
\hline & & 3 & 21 & 20 & 0 & 12 & 2 & 5 & 1 \\
\hline \multirow[t]{9}{*}{ pWX56 } & VIGS & 1 & 7 & 20 & 6 & 9 & 5 & 0 & 0 \\
\hline & & 2 & 7 & 20 & 17 & 0 & 0 & 3 & 0 \\
\hline & & 3 & 7 & 20 & 0 & 16 & 0 & 0 & 4 \\
\hline & & 1 & 14 & 20 & 13 & 2 & 3 & 0 & 2 \\
\hline & & 2 & 14 & 20 & 6 & 12 & 0 & 1 & 1 \\
\hline & & 3 & 14 & 20 & 11 & 4 & 0 & 5 & 0 \\
\hline & & 1 & 21 & 20 & 12 & 3 & 0 & 1 & 4 \\
\hline & & 2 & 21 & 20 & 12 & 3 & 0 & 1 & 4 \\
\hline & & 3 & 21 & 20 & 4 & 4 & 1 & 1 & $10^{c}$ \\
\hline
\end{tabular}

aThree experimental replicates (20 plants per construct in each), were tested by RT-PCR. Wild type pWX6 and healthy plants were used as positive and negative controls

${ }^{\mathbf{b}}$ RT-PCR results per sample were scored into 5 different categories (a,b,c,d and $\mathbf{e}$ ), based on band(s) observed: $\boldsymbol{a}$ full length insertion single band observed, $\boldsymbol{b}$ multiple bands observed; including expected full-length insertion and smaller bands indicating insert loss, $c$ multiple bands indicating insert loss, with none representing full length insertion; $\boldsymbol{d}$ single band detected at less than full-length insertion size, usually close to size of wild type virus amplicon; $\boldsymbol{e}$ no bands detected with primer pair

'This replicate was excluded from statistical analyses since no amplification was observed in half of the samples

can be used for simple rub-inoculation to new maize plants for easy scale-up. Stable VIGS or GFP insertion and expression in MDMV demonstrate that MDMV could be used as a powerful tool for gene function analysis and gene expression in maize. Although all proof of concept work reported here was performed in maize genotypes Early Sunglow and Silver Queen, the pWX56 construct also infected and induced VIGS 

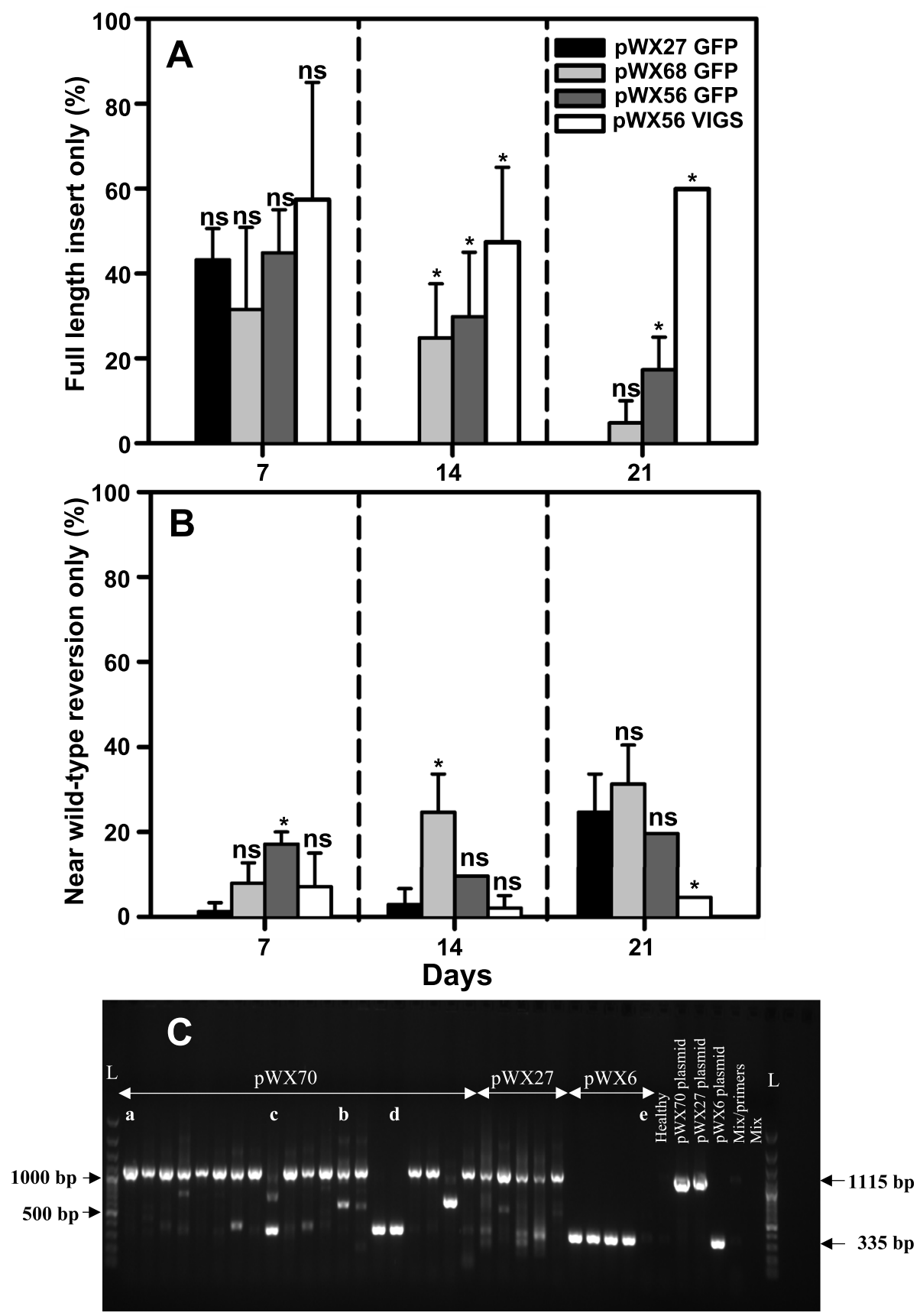

Fig. 5 Comparison of insert stability in MDMV OH5 constructs at 7, 14, and 21 dpi. Across three replicates of 20 plants per construct, plants infected with pWX27, pWX68, and pWX56 were assessed for integrity of insertion sequences using RT-PCR with primers flanking the insertion sites. Five plants inoculated with pWX6, the cloned wild type virus, were included for each replicate. For each sample, amplicons were scored in five categories (examples from pWX70 shown in panel C); as full length insert $\mathbf{a}$, full length insert plus smaller bands detected $\mathbf{b}$, multiple bands with no full length insert $\mathbf{c}$, single band of less than full-length insert usually near-wild type virus amplicon $\mathbf{d}$, and no band detected $\mathbf{e}$ (example from pWX6 sample shown), compared to plasmid controls pWX70, pWX27 and pWX6 (WT). The number of samples in which bands were scored in categories $\mathbf{a}$ and $\mathbf{d}$ (panel A and B, respectively) were compared statistically for each construct. At fixed assessment times, constructs designated "ns" were not significantly different from pWX27 GFP at $P \leq 0.05$ and constructs with * were significantly different from pWX27 GFP at $P \leq 0.05$ based on the pairwise comparisons of least squares mean on the arcsine-square root scale. Samples were taken from the youngest leaves of 7, 14 and 21 dpi of plants for RT-PCR analysis using primers: WX112/WX111 (pWX27); WX317/WX315 (pWX68); WX358/WX367 for GFP insertion (pWX56), and primers WX317/WX315 for VIGS insertion (pWX56). Example test samples shown in panel C are from 14 dpi inoculations with pWX70; $L=$ GeneRuler 100 bp Plus DNA ladder (ThermoFisher Scientific, USA) 
photobleaching in maize genotypes B73 and Mo17, suggesting that it can be utilized similarly in susceptible maize genotypes (preliminary data not shown). We also note for the benefit of end-users that optimal performance of pWX56 as reported here relies on optimal plant growth conditions: plants visibly stressed by poor growing conditions, in our case due to growth chamber malfunctions, showed marked and rapid loss of pWX56 insertion sequences when inoculated (results not shown).

Compared to other virus-based tools that are currently available for maize, (based on BMV, CMV, FoMV, SCMV, WSMV, BSMV, BYSMV, and MRFV), the multitarget and multi-function simultaneous VIGS/gene expression capability we report is a unique new development for grasses. Since each virus has unique features, and direct experimental and quantitative comparison of performance parameters of the various available virusbased tools for gene expression or gene silencing in maize have not been conducted, direct comparison of virus-based tools in maize is limited. However, published literature can aid in informing selection of a suitable tool for end-users based on different features such as carrying capacity, delivery method, insert stability, phenotype penetrance, and function, with the caveat that direct comparisons are imperfect due to the wide range of parameters utilized and measured in each system. As an additional caveat, it should also be noted that, in all virus systems examined and used for comparison, insertion stability as well as carrying capacity shows at least some sequence-dependence, thus there is not a strict carrying capacity or degree of stability for all possible insertion sequences.

The maximum sequence carrying capacity of constructs designed in the pattern of pWX56 was not examined. However, the total heterologous sequence carried by pWX56 (ca. $1.4 \mathrm{~kb}$ ) is much greater than that reported for maize-infecting tools based on viruses with spherical virions, which are expected to have physical constraints on insertion size and carry silencing target sequences ca. $300 \mathrm{nt}$ or smaller (BMV [20, 21], CMV [13], MRFV [22]). pWX56 sequence cargo size is comparable or slightly smaller than those reported for other viruses that also have rod-shaped virions, which may increase capsid length corresponding with increased sequence insertion. However, the modified rod-shaped viruses still have insertion size limitations, and generally have reduced performance and stability in maize with larger insertion sequences such as $\beta$-glucuronidase (GUS) (SCMV [27], WSMV [24-26], BSMV [31], and FoMV [29]). The BYSMV rhabdovirus tool is in a class by itself for overall carrying capacity, with one of the reported constructs carrying the large Cas 9 gene as well as sequence encoding scaffolded guide RNA and a red fluorescent protein gene, ca. $5 \mathrm{~kb}$ in total [33]. However, it should be noted that launching these negative sense RNA virus-based constructs in maize is difficult, requiring transmission from planthoppers injected with crude sap from Agrobacterium-inoculated Nicotiana benthamiana [33].

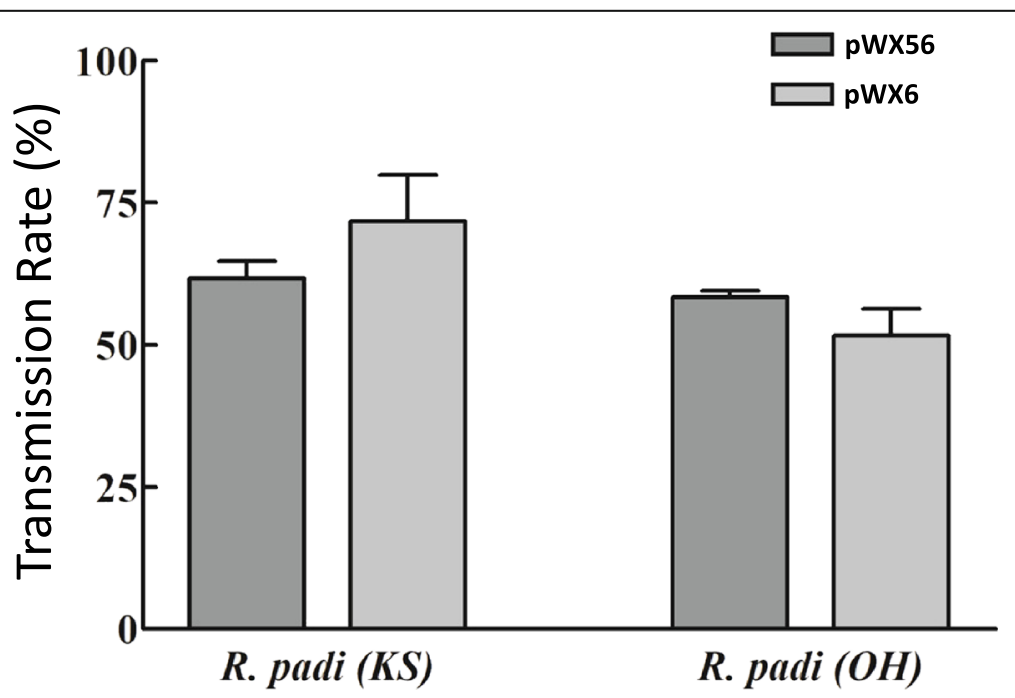

Fig. 6 Aphid transmission of virus launched from pWX56 vs. wild type control pWX6. A total of 20 plants each for pWX6 and pWX56 were aphid inoculated with the respective constructs, and infectivity was scored by observation of mosaic symptoms and RT-PCR analysis (data not shown). No statistical significance was observed between pWX6 and pWX56 transmission or between transmission by Kansas and Ohio-derived R. padi colonies. Samples were taken from the newest fully emerged leaf of 17 dpi of aphid feeding plants for RT-PCR analysis using primers WX358/ WX367 (1115 nt) for GFP insertion, and primers WX317/WX315 (965 nt) for VIGS insertion 
Insertion stability in virus-based tools, for maize as well as other plants, is a common challenge, and can limit utility to only a few leaves above inoculation points $[20,23]$. For insertion stability, pWX56 ranks among the most insert-stable virus-based tools for maize, such as the single protein expression tool based on the related virus SCMV [27], with insert retention and associated phenotypes observed systemically up to the last observation time points and topmost leaves, and up to three passages. However, its relative stability with progressive insert loss is not as impressive as the nearly complete insert retention over 60 days of the single-gene silencing tool based on MRFV [22]. Silencing efficacy of each of the target genes for pWX56, with gene expressions reduced to $39-46 \%$ of control expression levels, is within ranges expected for single-target VIGS BMV constructs (ca. 30-60\% of control expression) [21], but has lower apparent silencing penetrance than some single-target VIGS constructs (13-33\% of control expression in silenced tissue for BSMV [23], and 16-33\% of control expression for MRFV [22])--noting again that differences in methodology and conditions make such comparisons imprecise. Protein expression of GFP from pWX56 is also visually robust, but as no quantitative assessments were performed here beyond insertion and expression stability, we cannot compare protein expression quantity among available reported tools. The qualitative properties of simultaneous opposite functions of gene silencing and gene expression, and the capability for multiple silencing targets, make pWX56 and derivatives of this design a novel addition to the maize virus-based toolbox.

\section{Conclusions}

We demonstrated that an MDMV-derived vector can be used to express GFP protein and simultaneously silence three maize genes at the same time. We also showed that dual insertion enhanced the stability of inserted sequences.

\section{Materials and methods}

\section{Plant materials and inoculation}

MDMV OH5 was obtained from a Johnsongrass plant with mosaic symptoms collected from a field in Chillicothe, Ohio in October 2017 (public property collections and private property collections by permission of individual landowners were made, samples were not distinguished to original land ownership), and maintained in a greenhouse at Ohio State University (OSU) Wooster campus under OSU Institutional Biosafety Committee regulations. Plants were destructively sampled and not formally identified by taxonomic experts. Virus was transmitted from the source plant via rub inoculation by grinding leaf tissue in five volumes of $10 \mathrm{mM}$ potassium phosphate,
$\mathrm{pH}$ 7. Extract was rubbed onto leaves of 10 to 11 day old 'Oh28', 'Early Sunglow', and 'Silver Queen' between thumb and forefinger with inoculum mixed with 600-mesh silicon carbide (carborundum). All plant materials infected with modified virus constructs were grown in controlled growth chamber at $25^{\circ} \mathrm{C}$, $16 \mathrm{~h}$ light and $8 \mathrm{~h}$ dark conditions with light intensity of $13,000 \mathrm{~lm}$.

\section{Sequencing MDMV OH5}

Total RNA was isolated from four Johnsongrass samples (named MDMV OH3 to MDMV OH6) using Directzol RNA Miniprep Kit (Zymo Research, USA). Complementary DNA (cDNA) was synthesized and used for reverse transcription-PCR (RT-PCR). Primers specific to MDMV OH1 (MDMV-7065F, MDMV-4272F, MDMV genR1) were used for MDMV genome sequence amplification (Additional file 1: Table S1). Amplified DNA fragments were sequenced using the same primers above and MDMV-6241R. MDMV OH5 was used for subsequent studies.

Terminal sequences of MDMV were determined by $5^{\prime}$ - and $3^{\prime}$-RACE. For $5^{\prime}$-RACE, $1 \mu \mathrm{g}$ total nucleic acid extracted from MDMV-infected plants were first annealed with primer WX24 (Additional file 1: Table S1), then used for first strand cDNA synthesis using Superscript III reverse transcriptase (ThermoFisher Scientific, USA), followed by $\mathrm{RNaseH}$ treatment as described by the manufacturer (ThermoFisher Scientific, USA). The cDNA was then passed through a Monarch $^{\circ}$ PCR and DNA cleanup column (New England Biolabs, USA), quantified and G-tailed with $0.25 \mathrm{mM}$ dGTP by terminal transferase (New England Biolabs, USA). The G-tailed cDNA was used as template for PCR with primers WX25 and WX27, followed by a second amplification PCR with primers WX26 and WX29 (Additional file 1: Table S1). PCR amplified DNA was either sequenced directly using primer WX27 or cloned into pMINIT 2.0 vector (New England Biolabs, USA), then subject to sequencing. For 3 '-RACE, $1 \mu \mathrm{g}$ total nucleic acid extracted from MDMV-infected plants were first annealed with primer WX292 (Additional file 1: Table S1), then used for first strand cDNA synthesis using Superscript III reverse transcriptase (ThermoFisher Scientific, USA), followed by $\mathrm{RNaseH}$ treatment as described by the manufacturer (ThermoFisher Scientific, USA). The cDNA was then passed through a Monarch $^{\circ}$ PCR and DNA cleanup column (New England Biolabs, USA). The cDNA was used as template for PCR with primers WX236 and WX293, followed by a second PCR with primers WX29 and WX237. Amplified DNA was either sequenced directly using primer WX27 or cloned into pMINIT 2.0 vector (New England Biolabs, USA) and then subject to sequencing. 


\section{Creation of infectious CDNA clone of MDMV OH5}

Full-length cDNA from MDMV OH5 was cloned into a binary vector pJL89 [57]. cDNA was prepared from $1 \mu \mathrm{g}$ total RNA extracted from MDMV-infected plants, with first strand cDNA synthesis carried out using Superscript III reverse transcriptase and oligo $\mathrm{d}(\mathrm{T})$ primer, followed by $\mathrm{RNaseH}$ treatment as described by the manufacturer (ThermoFisher Scientific, USA). Fulllength MDMV genomic sequence was amplified from the MDMV first strand cDNA using primers LRS764 and LRS765 (Additional file 1: Table S1). The amplified cDNA sequence was then cloned into SmaI and StuIdigested binary vector pJL89 using NEBuilder ${ }^{\circledR} \mathrm{HiFi}$ DNA Assembly Master Mix (New England Biolabs, USA) as described by the manufacturer. Several infectious MDMV OH5 clones in pJL89 were obtained, one of which, named pWX6, was selected for sequencing and further analysis.

\section{Insertion of GFP at the N-terminal region of CP ( $\mathrm{pWX27)}$}

Green fluorescent protein (GFP) gene sequence [60] was inserted using NEBuilder HiFi Assembly Master Mix (New England Biolabs Inc., USA) in-frame between pWX6 NIb and CP coding sequences with a duplicated cleavage sites inserted between nt 8386/8387: 15 nt (5'CagGCcGGcGAgacc-3', lower case indicating nucleotides changed to alter codons while retaining translated sequence) encoding amino acid sequence Q/AGET, cleaved by NIa-Pro at the beginning of the GFP gene; and $24 \mathrm{nt}$ (5'-GAgGTtATcGAcGTgAAgCAcCAA-3') encoding NIb cleavage site amino acid sequence of EVIDVKHQ/) at the end of GFP. Primers WX123/ WX124 and WX126/WX127 were used to amplify the full-length GFP sequence, primers WX125/LRS764 and WX128/LRS765 for MDMV OH5 sequence, and LRS766/LRS769 were used to amplify the pJL89 vector (Additional file 1: Table S1). The GFP-encoding gene fragment was assembled into pWX6 using NEBuilder ${ }^{\bullet}$ HiFi DNA Assembly Master Mix (New England Biolabs, USA), and subsequent clones were tested for infectivity.

\section{Insertion of GFP at the N-terminal region of HCPro (pWX68)}

GFP sequence was also cloned using NEBuilder HiFi Assembly Master Mix (New England Biolabs Inc., USA) inframe between MDMV OH5 P1 and HCPro coding sequences with inserted NIb cleavage site sequence in pWX6 (nt 838/839), adding $12 \mathrm{nt} 5^{\prime}$ (5'-GCcGAtCCtacc- $\left.3^{\prime}\right)$, encoding amino acid sequence ADPT 5', and $33 \mathrm{nt}$ 3

$\left(5^{\prime}-\right.$ GAgGTAATcGAcGTgAAgCAcCAAGCcGGcGag-3'), encoding amino acid sequence EVIDVKHQ/AGE, cleaved by NIa-Pro) at the end of GFP. Nested primers WX36/WX37 and WX63/WX64 were used to amplify the full-length GFP gene sequence, and primers WX247 and WX250 were used to amplify pJL89 with MDMV sequence (Additional file 1: Table S1). The GFP gene fragment was assembled into pWX6 and recovered clones were tested for infectivity.

\section{Creation of a triple gene insertion in the $\mathrm{N}$-terminal region of HCPro ( $p W X 56)$}

Infectious clone pWX27 with GFP inserted between NIb and $\mathrm{CP}$ was used as backbone vector for a triple partial gene sequence cloning between P1 and HCPro. Three maize genes, magnesium chelatase ( $\mathrm{ZmChlI,} \mathrm{GenBank}$ accession no. DQ084025, target region: 946-1193), lemon white $1(\mathrm{ZmIspH}$, GenBank accession no. NM_ 001175829, target region: 740-988) and phytoene desaturase ( $Z m$ PDS, GenBank accession no. L39266, target region: 538-786) were selected for VIGS analysis. The triple gene fragment, 249 nt of each gene with total length of $747 \mathrm{nt}$, was synthesized (Eurofins Genomics, USA), cloned into pMINIT2.0 vector and verified by sequencing. The triple VIGS gene fragment was then amplified by PCR with primers WX251 and WX252, and the pWX27 backbone was amplified using primers WX247 and WX250, assembled using NEBuilder HiFi Assembly Master Mix (New England Biolabs Inc., USA) in-frame between P1 and HCPro to create pWX56. The triple VIGS DNA fragment contained nine additional $5^{\prime} \mathrm{nt}$ (5'-GCcGAtCCt-3') encoding amino acid sequence ADP at the beginning of the VIGS insertion, and $33 \mathrm{nt}$ 3' (5' - GAgGTAATcGAcGTgAAgCAcCAAGCcGGcGa g-3'), encoding NIb cleavage site amino acid sequence of EVIDVKHQ/AGE, cleaved by NIa-Pro), between nt 838/839 of pWX27. Recovered clones were tested for infectivity and one infectious clone, pWX56, was selected for further analysis.

\section{Infectivity testing by vascular puncture inoculation of in vitro transcripts}

All full-length virus constructs were amplified by polymerase chain reaction (PCR) from plasmid DNA templates using primers containing $5^{\prime} \mathrm{T} 7$ promoter sequences, WX3 (Table S1) and reverse primer MDMV GenR1 [52] complementary to the $3^{\prime}$-most 17 nt of the MDMV 3-terminal sequence and adding a $21 \mathrm{nt}$ of poly(A) to the virus-sense strand of the amplicon. PCR was performed using PrimeSTAR GXL DNA Polymerase from Takara Bio USA (Mountain View, CA) according to manufacturer's instructions.

In vitro RNA transcripts were synthesized using T7 ARCA RNA transcription kit (New England Biolabs, USA) rather than the transcription kit used for previous work reporting MDMV OH1 infectious clone [52] and cleaned using with $2 \mathrm{M}$ lithium chloride or the 
Monarch RNA cleanup kit (New England Biolabs, USA). Transcript quantity was estimated by NanoDrop (ThermoFisher Scientific, USA) and quality was assessed on non-denaturing $1 \%$ agarose $1 \mathrm{X}$ TBE $(0.089$ M Tris, $0.089 \mathrm{M}$ boric acid, 0.002 M EDTA) gels.). Vascular puncture inoculation (VPI) was used to inoculate 'Silver Queen' maize seeds with $2.0 \mu \mathrm{g}$ RNA transcript per seed as previously described $[45,50]$. Inoculated seeds were germinated for two days at $30^{\circ} \mathrm{C}$, sown into sterilized soil, and grown in a growth chamber at $25^{\circ} \mathrm{C}$, $16 \mathrm{~h}$ light and $8 \mathrm{~h}$ dark conditions with light intensity of $13,000 \mathrm{~lm}$. Infectivity of constructs was tested by reverse transcription polymerase chain reaction (RT$\mathrm{PCR}$ ) on leaves from individual plants with primers testing for MDMV (WX111 and WX112). RT-PCR was performed on fresh samples at each time point by grinding samples $1: 20(\mathrm{~g} / \mathrm{mL})$ in grape extraction buffer (GEB: $0.05 \mathrm{M}$ sodium carbonate buffer pH 9.6, 2\% polyvinylpyrrolidone- $40,0.2 \%$ bovine serum albumin, $0.05 \%$ Tween-20), then boiling the samples diluted $4 \mu \mathrm{l}$ into $50 \mu \mathrm{l}$ of at $95^{\circ} \mathrm{C}$ for $10 \mathrm{~min}$ in GES buffer $(0.1 \mathrm{M}$ glycine- $\mathrm{NaOH}$ pH 9.0, $50 \mathrm{mM} \mathrm{NaCl}, 1 \mathrm{mM}$ EDTA, $0.5 \%$ Triton X-100, and .01\% beta-mercaptoethanol. Onestep RT-PCR was performed with SuperScript III reverse transcriptase (Invitrogen, Carlsbad, CA) and GoTaq polymerase (Promega Corp., Madison, WI) at $52^{\circ} \mathrm{C}$ for $40 \mathrm{~min}$. Followed by $2 \mathrm{~min}$ at $94{ }^{\circ} \mathrm{C}$ and $32 \mathrm{cy}-$ cles of $94{ }^{\circ} \mathrm{C}$ for $15 \mathrm{~s}, 55^{\circ} \mathrm{C}$ for $20 \mathrm{~s}$, and $72^{\circ} \mathrm{C}$ for $1 \mathrm{~min}$, ending with a $7 \mathrm{~min} .72^{\circ} \mathrm{C}$ extension.

Rub inoculation scale-up from transcript-infected material To scale up infection with constructs after VPI inoculation with transcripts, VPI-infected leaves were harvested as early as systemic symptoms could be robustly confirmed (7-10 dpi), to maximize virus harvest while minimizing replication cycles in which insert can be lost, and stored at $-80^{\circ} \mathrm{C}$ for up to 3 months in $0.5 \mathrm{~g}$ aliquots. Frozen tissue was ground in five volumes of $10 \mathrm{mM} \mathrm{pH} 7$ potassium phosphate buffer with 600-mesh silicon carbide (carborundum) added as abrasive. Extract was then rubbed onto leaves of 8 to 10-day old corn plants using thumb and forefinger, with $0.5 \mathrm{~g}$ frozen tissue providing enough inoculum for 20 plants and resulting in infection rates near $100 \%$. Plants were symptomatic 5-7 days post rub inoculation.

\section{Visualization of GFP expression}

GFP expression was visualized on leaves of $Z$. mays 'Silver Queen' at 7, and 21 days post rub inoculation. Images were taken with a Leica DFC460C (Leica Microsystems, USA) camera using fluorescence imaging with NIGHTSEA Greenonly bandpass filter (NIGHTSEA, USA) at 3-s exposure to separate green fluorescence from maize autofluorescence. Brightfield images were taken at 1-s exposure.

\section{Western blotting}

GFP protein expression was assessed by Western blotting. Plant tissue that tested positive by RT-PCR with primers WX358 and WX367 was saved at $-80^{\circ} \mathrm{C}$, for each time point of 7,14 , and 21 days post rub inoculation, and later used for Western blotting. Thawed tissue was ground in $1 \mathrm{ml}$ of radioimmunoprecipitation assay (RIPA) buffer amended with one tablet cOmplete, Mini, EDTA-free Protease Inhibitor Cocktail (Millipore-Sigma, USA) and $300 \mu \mathrm{l} 1 \mathrm{M}$ dithiothreitol (DTT) per $10 \mathrm{ml}$ of buffer. Ground tissue was centrifuged at $16,000 \mathrm{~g}$ at $4{ }^{\circ} \mathrm{C}$ for $20 \mathrm{~min}$. Supernatant was transferred to new Eppendorf tubes and placed on ice for remainder of experiment. Total protein was determined using Pierce 660 nm Protein Assay kit and Pierce BCA Protein standards (ThermoFisher Scientific, USA) in a 96 well plate with 3 reps per sample.

Equal parts of leaf supernatant and 2X Laemmli sample buffer (Bio-Rad, USA) were mixed, boiled for $3 \mathrm{~min}$ and allowed to cool. Samples were loaded onto 4-20\% Mini-PROTEAN TGX Stain-Free Protein Gels (Bio-Rad, USA) at $25 \mu \mathrm{g}$ total protein per lane. Recombinant $E$. coli GFP Protein (Abcam, USA) was loaded at $5 \mathrm{ng}$ as a positive control. Lysates were electrophoresed in Tris/Glycine/SDS buffer ( $25 \mathrm{mM}$ Tris; pH 8.8, $200 \mathrm{mM}$ glycine, $0.1 \%$ sodium dodecyl sulfate) at $200 \mathrm{~V}$ for $30 \mathrm{~min}$. Proteins were transferred using Trans-Blot Turbo Transfer System on Trans-Blot Turbo Nitrocellulose Transfer Pack (Bio-Rad, USA) paper at $25 \mathrm{~V}$ for 7 mins. Membranes were blocked in 5\% nonfat dry milk (NFDM) in TBS buffer ( $50 \mathrm{mM}$ Tris and $150 \mathrm{mM} \mathrm{NaCl}, \mathrm{pH} 7.5)$ for $1 \mathrm{~h}$. Membranes were incubated on a shaker at room temperature for $1 \mathrm{~h}$ with 1:3000 Anti-GFP antibody (Abcam, USA) in 1\% TBS-T (TBS buffer with $0.1 \%$ Tween-20). Membranes were washed for 10 min 3 times in TBS-T. Membranes were incubated with 1:2500 Goat Anti-Rabbit IgG H\&L (Abcam, USA) for $1 \mathrm{~h}$ and then washed for $5 \mathrm{~min} 3$ times in TBS-T. Proteins were visualized by chemiluminescence using Clarity Western ECL Substrate (Bio-Rad, USA) on a ChemiDoc XRS System (Bio-Rad, USA).

\section{RT-PCR insertion stability assays}

Twenty plants were rub-inoculated with wild type and modified MDMV with GFP insert using verified VPIsourced plant sap. Samples were collected at 7, 14, and 21 days post-rub inoculation from the youngest fully emerged leaf. Plant samples were screened by RT-PCR using the same method described above. Primers spanning whole GFP and GFP internal primers with MDMV $\mathrm{OH} 5$ either upstream or downstream GFP insertion 
were used for RT-PCR analysis. Amplified DNA was electrophoresed on $1 \%$ agarose gels. Leaf samples were collected as described above and analyzed for insertion stability and quantified using either semi-quantification RT-PCR.

Individual target genes of triple VIGS insertion were confirmed using one of MDMV OH5 specific primers either upstream (WX317) or downstream (WX315) of the triple VIGS insertion and specific primers (WX321 for $Z m$ ChII, WX325 for ZmIspH, and WX327 for ZmPDS) to each of three target genes of magnesium chelatase, lemon white 1 and phytoene desaturase ( $\mathrm{ZmChlI-IspH-}$ PDS; triple VIGS). Photobleaching symptoms were observed and photographed, and chlorophyll content was measured with a MC-100 Chlorophyll Concentration Meter following manufacturer's instructions (Apogee Instruments, USA). Three measurements were done for each leaf.

\section{RT-qPCR to quantify gene silencing}

Leaf samples were collected 7, 14, and 21 days post-rub inoculation, total RNA was extracted as described above and quantified using either semi-quantitative RT-PCR or RT-qPCR. One microgram total RNA from each sample was used for cDNA synthesis in a $20 \mu \mathrm{l}$ reaction by using iScript $^{\mathrm{Tm}}$ Reverse Transcription Supermix (Bio-Rad, USA). Primer efficiency was determined using $1 \mu \mathrm{l}$ cDNA at $1 / 5,1 / 10,1 / 20,1 / 40$ and $1 / 160$ dilutions (Additional file 1: Table S6). qPCR was carried out by using SsoAdvanced Universal SYBR Green Supermix (Bio-Rad, USA) in a Bio-Rad's CFX96 real-time C1000 touch thermal cycler under conditions of $95^{\circ} \mathrm{C}$ for $30 \mathrm{~s}, 39$ cycles of: $95^{\circ} \mathrm{C}$ for $10 \mathrm{~s}$ and $60^{\circ} \mathrm{C}$ for $30 \mathrm{~s}$, then $95^{\circ} \mathrm{C}$ for $10 \mathrm{~s}$, melt curve $65^{\circ} \mathrm{C}$ to $95^{\circ} \mathrm{C}$ with an increment of $0.5^{\circ} \mathrm{C}, 5$ s. All samples were run with cDNA dilution of 1:5, cDNA derived from $10 \mathrm{ng}$ total RNA. Gene quantification and analysis was done on target genes of $Z m C h l I$, $\mathrm{ZmIspH}, \mathrm{ZmPDS}$ as well as GFP, MDMV, and along with reference genes of membrane protein PB1A10.07c (MEP) and folypolyglutamate synthase (FPGS) [61]. Primers used for RT-qPCR analysis are shown in (Additional file 1: Table S1, S6). Ct was determined using $\mathrm{E}=$ $10^{\wedge}[-1 /$ slope $]$ (Additional file 1: Table S6).

\section{Aphid transmission assays}

Wild type MDMV OH5 and modified MDMV OH5 derived VIGS were transmitted by Rhopalosiphum padi. $R$. padi were maintained on virus-free 'Early Sunglow' maize plants in the cages at $25^{\circ} \mathrm{C}$ with a photoperiod of $15 \mathrm{~h}$ light/ $9 \mathrm{~h}$ dark. 'Silver Queen' maize plants were inoculated by VPI with in vitro RNA transcript. The infected tissues were collected and kept at $-80{ }^{\circ} \mathrm{C}$, which were used for rub inoculation. The virus source plants were prepared by rub inoculating seven-day-old seedlings 'Early Sunglow' with the VPI tissue and the plants were kept at $20^{\circ} \mathrm{C}$ with a photoperiod of $15 \mathrm{~h}$ light/ $9 \mathrm{~h}$ dark for 14 days. The leaves with strong MDMV symptoms (usually the $1 / 3$ from tip in the 2 nd leaf of plant) were sprayed with $10 \%$ sucrose, and were left to dry out before collection. The collected leaf was then cut into smaller pieces (around $1 \mathrm{~cm}^{2}$ ) and were placed in a small box (around $10 \mathrm{~cm}^{3}$ ) lined with wet tissue paper for maintaining the moisture. $R$. padi were then fed on source plants in the box for $10 \mathrm{~min}$ (acquisition access period), and after acquisition period, 10 aphids were moved onto the corn whorl per plant with 20 healthy 'Early Sunglow' plants in total for each treatment. The plants were covered with a plastic tube for 3 days, and then aphids were removed by NUVAN PROSTRIPS (AMVAC Chemical Corporation, USA) for 2-4 h. Symptoms was scored at 7 , and 14 days postinoculation and infection was further confirmed by RTPCR using primers WX317/WX315 for VIGS, and WX368/WX357 for GFP insertion.

\section{Statistical analysis}

Insert stability in MDMV OH5 constructs at 7, 14, and 21 dpi was analyzed statistically. Constructs of pWX27, pWX68, and pWX56, three replicates of 20 plants inoculated per construct, were examined for integrity of insertion sequences using RT-PCR with primers flanking the insertion sites. Linear mixed model was used to analyze the effects of constructs, time, and their interactions on band types. F-statistics and probability values from the fit of linear mixed models to arcsine-square root transformed bands data. Data were arcsine-square-root transformed prior to analysis to stabilize variance. Since data were collected as temporal repeated measures on the same experimental units and as such were correlated in time, the random_residual_statement and type option in GLIMMIX were used to account for, and model, the covariance structure (compound symmetry) of the within-subject data. Models were fitted using the GLIM MIX procedure of SAS.

\section{Abbreviations}

CP: Coat protein; CDNA: Complementary DNA; GFP: Green fluorescent protein; HCPro: Helper component proteinase; MDMV: Maize dwarf mosaic virus; NIb-RdRP: Nuclear inclusion b-RNA-dependent RNA polymerase; $R$. padi: Rhopalosiphum padi; RT-PCR: Reverse transcription-polymerase chain reaction; ZmChll: Zea mays magnesium chelatase; $Z \mathrm{mlspH}$ : Zea mays lemon white 1; ZmPDS: Zea mays phytoene desaturase (ZmChll-IspH-PDS; VIGS: Virusinduced gene silencing; VPI: Vascular puncture inoculation

\section{Supplementary Information}

The online version contains supplementary material available at https://doi. org/10.1186/s12870-021-02971-1.

Additional file 1: Table S1. Primers used in cloning, vector construction, RT-PCR and RT-qPCR. Table S2. Summary statistics from 
linear mixed model analyses of the effects of constructs, time, and their interactions on band types. Table $\mathbf{S 3}$. Probability values ( $p$-values) for pairwise comparisons of least squares means between constructs at fixed levels of assessment time from linear model mixed analyses of the effects of constructs, and assessment time on arcsine-square root-transformed bands data. Table S4. Probability values ( $p$-values) for pairwise comparisons of least squares means between assessment times at fixed construct from linear model mixed analyses of the effects of constructs, and assessment time on arcsine-square root-transformed bands data. Table S5. Passaging test of pWX56 for GFP expression and VIGS photobleaching.

Table S6. Target and reference genes used in RT-qPCR analysis.

Additional file 2: Figure S1. Analysis of pWX56 infected plants. A. RTPCR analysis of target gene insertion of pWX56 plant 40 days post VPI, lanes: MDMV-VIGS (primers WX317/WX176: 938 bp); MDMV-ZmChll (primers WX291/WX321: 382 bp); MDMV-ZmlspH (primers WX291/ WX325:636 bp), MDMV-ZmPDS (primers WX327/WX315:413 bp); pWX56infected plant (lanes 2-5); pWX6-infected plant (lane 6, with primers WX317NX315: 176 bp); pWX56 DNA control (primers WX317/WX315: $965 \mathrm{bp}$ ) (lane 8). B. Chlorophyll content measurement ( $\mu \mathrm{mol}$ per $\mathrm{m}^{2}$ ) of newest fully emerged leaf of each plant: healthy $(\mathrm{HC}), \mathrm{pWX} 6$, and pWX56. C. Representative images of GFP and photobleaching after pWX56 rubinoculation passages (see Table S5). OP = plant rub-inoculated from VPI tissue, $1 \mathrm{P}-5 \mathrm{P}=$ plants rub-inoculated with $14 \mathrm{dpi}$ pooled tissue from prior inoculation, all shown 14 dpi. Images were taken with a Leica DFC $460 C$ camera using fluorescence imaging with NIGHTSEA Green-only bandpass filter at 3-s exposure and bottom panel images are taken with the same camera without fluorescence at $1 \mathrm{~s}$ exposure. D. pWX56-infected whole plant silencing 90 days post inoculation. Figure S2. Representative gels showing GFP and VIGS insertion stability analysis by RT-PCR. A. pWX27inoculated plants tested with primers WX111/112 (Table S1) spanning $\mathrm{Nlb} / \mathrm{CP}$ insertion site. B. pWX68-inoculated plants tested with primers WX315/317 (Table S1) spanning P1/HCPro insertion site. C. pWX56 [GFP] tested with primers WX358/367 (Table S1) spanning Nlb/CP insertion site. D. pWX56 [VIGS] tested with primers WX315/317 (Table S1) spanning P1/HCPro insertion site. For each construct, assays from 20 rubinoculated plants are shown in first lanes, followed by control assays from either five pWX6-inoculated control plants and five mock-inoculated control plants (A-B) or five pWX27-inoculated, five pWX6-inoculated, and five mock-inoculated control plants (C-D). Samples of the newest fully emerged leaf from top of each test plant was collected and fresh tissue used for one-step RT-PCR at 7, 14, and 21 days post inoculation as indicated, with gradient of bands shown spliced from three gels in each rightmost panel. Expected full-length amplicon sizes for test construct (top) vs. pWX6 no-insert control (bottom) with arrows to the left of each leftmost panel. Figure $\mathbf{S 3}$. Analysis of pWX56 infected plants transmitted by aphids R. padi. A. Photobleaching phenotype of pWX56 infected plants Cv. Early Sunglow by aphid R. padi 28 days post aphid transmission. HC: healthy plant; WT: wild type pWX6 infected plant; L1-L5 leaves of pWX56 infected plant from newest (L1) to oldest (L5) leaves, photographed at 28 days post transmission. B. Aphid transmission of pWX56 inoculum using the newest fully emerged young leaves from top of the plants were collected, GFP and VIGS were assayed at 17 days post inoculation by PCR with primers spanning the insertion site. pWX6: wild type MDMV OH5 transmitted plants; controls: pWX56 plasmid DNA and PCR master mix without template. Expected amplified PCR fragment sizes: pWX56 GFP full-length insert vs WT: WX358/WX367 (1115 bp vs. 335 bp); pWX56 VIGS WX317/WX315 (965 bp vs. 176 bp).

Additional file 3: Raw gel and blot images for Fig. 3. Raw gel images for Additional file 2: Figure $\mathbf{S 2}$.

\section{Acknowledgements}

We thank Jane Todd and Mark Jones of USDA for field Johnsongrass sample collection, Jodi Livesay for technical assistance, Dr. Tim Sit of the North Carolina State University for the GFP clone and the late Dr. Raymond Louie for advice on vascular puncture inoculation techniques.

\section{Authors' contributions}

LRS led the project design, data interpretation, and manuscript preparation. WX designed cloning strategies and created virus constructs, NK tested construct infectivity, and DM led expression and stability analyses with NK. JX tested aphid transmissibility of constructs. LRS, WX, DM, and JX designed experiments; WX, DM, JX, NK and KW performed the work, analyzed the data and assisted in writing the manuscript. WBM performed statistical analyses. All authors have read and approved the final manuscript.

\section{Funding}

This research was sponsored by the Defense Advanced Research Projects Agency (DARPA) and was accomplished under cooperative agreement number HR0011-17-2-0054. Within the framework of the project aims, experimental design, collection, analyses, interpretation and writing were performed solely by authors and not by the funding entities. The views expressed are those of the author and should not be interpreted as representing the official views or policies of the U.S. Government. The U.S. Government is authorized to reproduce and distribute reprints for Government purposes notwithstanding any copyright notation hereon. This research was supported in part by the U.S. Department of Agriculture, Agricultural Research Service. Mention of trade names or commercial products in this publication is solely for the purpose of providing specific information and does not imply recommendation or endorsement by the U.S. Department of Agriculture. USDA is an equal opportunity provider and employer.

\section{Availability of data and materials}

Reasonable requests will be fulfilled provided that written materials transfer and/or licensing agreements, and appropriate APHIS permits and containment requirements are in place. Requests should be directed to the corresponding author. The complete sequence of the cloned Johnsongrassderived field MDMV isolate was named MDMV OH5 and deposited as GenBank accession no. MN615724.

\section{Declarations}

\section{Ethics approval and consent to participate}

Samples were collected both from public property and from private landowners in the area. Although verbal permission was obtained wherever possible, the ownership of the land from which the cloned MDMV OH5 isolate was obtained was not recorded at the time of collection. Collections were compliant with national guidelines, which do not restrict collection at sites visited; use of materials complied with USDA-APHIS approved containment practices. No license(s) apply to collected materials. Plant samples were used to destructively isolate RNA and plant viruses and were not herbarium deposited.

\section{Consent for publication}

Not applicable.

\section{Competing interests}

The authors declare they have no competing interests.

\section{Author details}

'Department of Plant Pathology, Ohio State University, OH 44691 Wooster, USA. ${ }^{2}$ USDA-ARS Corn Soybean and Wheat Quality Research Unit, Wooster, $\mathrm{OH}$ 44691, USA.

Received: 6 October 2020 Accepted: 13 April 2021

Published online: 05 May 2021

References

1. Ranum P, Pena-Rosas JP, Garcia-Casal MN. Global maize production, utilization, and consumption. Ann N Y Acad Sci. 2014;1312(1):105-12. https://doi.org/10.1111/nyas.12396.

2. Schnable PS, Ware D, Fulton RS, Stein JC, Wei F, Pasternak S, et al. The B73 maize genome: complexity, diversity, and dynamics. Science. 2009; 326(5956):1112-5. https://doi.org/10.1126/science.1178534.

3. Yadava P, Abhishek A, Singh R, Singh I, Kaul T, Pattanayak A, et al. Advances in maize transformation technologies and development of transgenic maize. Front Plant Sci. 2016:7:1949.

4. Pogue GP, Lindbo JA, Garger SJ, Fitzmaurice WP. Making an ally from an enemy: plant virology and the new agriculture. Annu Rev Phytopathol. 2002;40(1):45-74. https://doi.org/10.1146/annurev.phyto.40.021102.150133. 
5. Scholthof $H B$, Scholthof $K B$, Jackson AO. Plant virus gene vectors for transient expression of foreign proteins in plants. Annu Rev Phytopathol. 1996;34(1):299-323. https://doi.org/10.1146/annurev.phyto.34.1.299.

6. Scholthof KB, Mirkov TE, Scholthof HB. Plant virus gene vectors: biotechnology applications in agriculture and medicine. Genet Eng (N Y). 2002;24:67-85. https://doi.org/10.1007/978-1-4615-0721-5_4

7. Scofield SR, Nelson RS. Resources for virus-induced gene silencing in the grasses. Plant Physiol. 2009;149(1):152-7. https://doi.org/10.1104/pp.108.128702.

8. Becker A, Lange M. VIGS--genomics goes functional. Trends Plant Sci. 2010; 15(1):1-4. https://doi.org/10.1016/j.tplants.2009.09.002.

9. Dommes AB, Gross T, Herbert DB, Kivivirta Kl, Becker A. Virus-induced gene silencing: empowering genetics in non-model organisms. J Exp Bot. 2019; 70(3):757-70. https://doi.org/10.1093/jxb/ery411.

10. Robertson D. VIGS vectors for gene silencing: many targets, many tools. Annu Rev Plant Biol. 2004;55(1):495-519. https://doi.org/10.1146/annurev.a rplant.55.031903.141803.

11. Singh DK, Lee HK, Dweikat I, Mysore KS. An efficient and improved method for virus-induced gene silencing in sorghum. BMC Plant Biol. 2018;18(1):123. https://doi.org/10.1186/s12870-018-1344-z.

12. van der Linde K, Doehlemann G. Utilizing virus-induced gene silencing for the functional characterization of maize genes during infection with the fungal pathogen Ustilago maydis. Methods Mol Biol. 2013;975:47-60. https://doi.org/10.1007/978-1-62703-278-0 4

13. Wang $R$, Yang $X$, Wang N, Liu X, Nelson RS, Li W, et al. An efficient virusinduced gene silencing vector for maize functional genomics research. Plant J. 2016;86(1):102-15. https://doi.org/10.1111/tpj.13142.

14. Zhou T, Liu X, Fan Z. Use of a virus gene silencing vector for maize functional genomics research. Methods Mol Biol 2018. 1676:141-50.

15. Kant R, Dasgupta I. Phenotyping of VIGS-mediated gene silencing in rice using a vector derived from a DNA virus. Plant Cell Rep. 2017;36(7):1159-70. https://doi.org/10.1007/s00299-017-2156-6.

16. Gleba Y, Klimyuk V, Marillonnet S. Viral vectors for the expression of proteins in plants. Curr Opin Biotechnol. 2007;18(2):134-41. https://doi.org/10.1016/j. copbio.2007.03.002.

17. Hefferon K: Plant Virus Expression Vectors: A Powerhouse for Global Health. Biomedicines 2017, 5(3)

18. Hefferon KL. Plant virus expression vectors set the stage as production platforms for biopharmaceutical proteins. Virology. 2012;433(1):1-6. https:// doi.org/10.1016/j.virol.2012.06.012.

19. Zhang CQ, Bradshaw JD, Whitham SA, Hill JH. The development of an efficient multipurpose bean pod mottle virus viral vector set for foreign gene expression and RNA silencing. Plant Physiol. 2010;153(1):52-65. https:// doi.org/10.1104/pp.109.151639

20. Ding XS, Schneider WL, Chaluvadi SR, Mian MA, Nelson RS. Characterization of a brome mosaic virus strain and its use as a vector for gene silencing in monocotyledonous hosts. Mol Plant-Microbe Interact. 2006;19(11):1229-39. https://doi.org/10.1094/MPMl-19-1229.

21. Ding XS, Mannas SW, Bishop BA, Rao X, Lecoultre M, Kwon S, et al. An improved brome mosaic virus silencing vector: greater insert stability and more extensive VIGS. Plant Physiol. 2018;176(1):496-510. https://doi.org/10.1104/pp.17.00905.

22. Mlotshwa S, Xu J, Willie K, Khatri N, Marty D, Stewart LR. Engineering maize rayado fino virus for virus-induced gene silencing. Plant Direct. 2020;4(8): e00224. https://doi.org/10.1002/pld3.224.

23. Jarugula S, Willie K, Stewart LR. Barley stripe mosaic virus (BSMV) as a virusinduced gene silencing vector in maize seedlings. Virus Genes. 2018;54(4): 616-20. https://doi.org/10.1007/s11262-018-1569-9.

24. Tatineni S, McMechan AJ, Hein GL, French R. Efficient and stable expression of GFP through wheat streak mosaic virus-based vectors in cereal hosts using a range of cleavage sites: formation of dense fluorescent aggregates for sensitive virus tracking. Virology. 2011;410(1):268-81. https://doi.org/10.1 016/j.virol.2010.10.043.

25. Choi IR, Horken KM, Stenger DC, French R. Mapping of the P1 proteinase cleavage site in the polyprotein of wheat streak mosaic virus (genus Tritimovirus). J Gen Virol. 2002;83(Pt 2):443-50. https://doi.org/10.1099/ 0022-1317-83-2-443.

26. Choi IR, Stenger DC, Morris TJ, French R. A plant virus vector for systemic expression of foreign genes in cereals. Plant J. 2000;23(4):547-55. https://doi. org/10.1046/j.1365-313x.2000.00820.x.

27. Mei Y, Liu G, Zhang C, Hill JH, Whitham SA. A sugarcane mosaic virus vector for gene expression in maize. Plant Direct. 2019;3(8):e00158. https://doi. org/10.1002/pld3.158.
28. Mei Y, Zhang CQ, Kernodle BM, Hill JH, Whitham SA. A foxtail mosaic virus vector for virus-induced gene silencing in maize. Plant Physiol. 2016;171(2): 760-72. https://doi.org/10.1104/pp.16.00172.

29. Bouton C, King RC, Chen HX, Azhakanandam K, Bieri S, Hammond-Kosack $\mathrm{KE}$, et al. Foxtail mosaic virus: a viral vector for protein expression in cereals. Plant Physiol. 2018;177(4):1352-67. https://doi.org/10.1104/pp.17.01679.

30. Mei Y, Beernink BM, Ellison EE, Konecna E, Neelakandan AK, Voytas DF, et al. Protein expression and gene editing in monocots using foxtail mosaic virus vectors. Plant Direct. 2019;3(11):e00181. https://doi.org/10.1002/pld3.181.

31. Cheuk A, Houde M. A new barley stripe mosaic virus allows large protein overexpression for rapid function analysis. Plant Physiol. 2018;176(3):191931. https://doi.org/10.1104/pp.17.01412.

32. Hu J, Li S, Li Z, Li H, Song W, Zhao H, et al. A barley stripe mosaic virusbased guide RNA delivery system for targeted mutagenesis in wheat and maize. Mol Plant Pathol. 2019:20(10):1463-74. https://doi.org/10.1111/ mpp.12849.

33. Gao Q, Xu WY, Yan T, Fang XD, Cao Q, Zhang ZJ, et al. Rescue of a plant cytorhabdovirus as versatile expression platforms for planthopper and cereal genomic studies. New Phytol. 2019;223(4):2120-33. https://doi.org/1 $0.1111 /$ nph.15889

34. Revers F, Garcia JA. Molecular biology of potyviruses. Adv Virus Res. 2015;92: 101-99. https://doi.org/10.1016/bs.aivir.2014.11.006.

35. Dolja W, McBride HJ, Carrington JC. Tagging of plant potyvirus replication and movement by insertion of beta-glucuronidase into the viral polyprotein. Proc Natl Acad Sci U S A. 1992;89(21):10208-12. https://doi. org/10.1073/pnas.89.21.10208.

36. Bedoya L, Martinez F, Rubio L, Daros JA. Simultaneous equimolar expression of multiple proteins in plants from a disarmed potyvirus vector. $J$ Biotechnol. 2010;150(2):268-75. https://doi.org/10.1016/j.jbiotec.2010.08.006.

37. Arazi T, Slutsky SG, Shiboleth YM, Wang Y, Rubinstein M, Barak S, et al. Engineering zucchini yellow mosaic potyvirus as a non-pathogenic vector for expression of heterologous proteins in cucurbits. J Biotechnol. 2001; 87(1):67-82. https://doi.org/10.1016/S0168-1656(01)00229-2.

38. Fernandez-Fernandez MR, Mourino M, Rivera J, Rodriguez F, Plana-Duran J, Garcia JA. Protection of rabbits against rabbit hemorrhagic disease virus by immunization with the VP60 protein expressed in plants with a potyvirus-based vector. Virology. 2001;280(2):283-91. https://doi.org/10.1006/viro.2000.0762.

39. Kelloniemi J, Makinen K, Valkonen JP. A potyvirus-based gene vector allows producing active human S-COMT and animal GFP, but not human sorcin, in vector-infected plants. Biochimie. 2006;88(5):505-13. https://doi.org/10.1016/ j.biochi.2005.10.010

40. Rajamaki ML, Kelloniemi J, Alminaite A, Kekarainen T, Rabenstein F, Valkonen JP. A novel insertion site inside the potyvirus P1 cistron allows expression of heterologous proteins and suggests some P1 functions. Virology. 2005; 342(1):88-101. https://doi.org/10.1016/j.virol.2005.07.019.

41. Kelloniemi J, Makinen K, Valkonen JP. Three heterologous proteins simultaneously expressed from a chimeric potyvirus: infectivity, stability and the correlation of genome and virion lengths. Virus Res. 2008;135(2):282-91. https://doi.org/10.1016/j.virusres.2008.04.006.

42. Beauchemin C, Bougie V, Laliberte JF. Simultaneous production of two foreign proteins from a polyvirus-based vector. Virus Res. 2005;112(1-2):1-8. https://doi.org/10.1016/j.virusres.2005.03.001.

43. Chen CC, Chen TC, Raja JA, Chang CA, Chen LW, Lin SS, et al. Effectiveness and stability of heterologous proteins expressed in plants by turnip mosaic virus vector at five different insertion sites. Virus Res. 2007;130(1-2):210-27. https://doi.org/10.1016/j.virusres.2007.06.014.

44. Gao R, Tian YP, Wang J, Yin X, Li XD, Valkonen JP. Construction of an infectious CDNA clone and gene expression vector of tobacco vein banding mosaic virus (genus Potyvirus). Virus Res. 2012;169(1):276-81. https://doi. org/10.1016/j.virusres.2012.07.010

45. Gammelgard E, Mohan M, Valkonen JP. Potyvirus-induced gene silencing: the dynamic process of systemic silencing and silencing suppression. J Gen Virol. 2007;88(Pt 8):2337-46. https://doi.org/10.1099/vir.0.82928-0.

46. Janson BF, Ellett CW. A new corn disease in Ohio. Plant Dis Report. 1963:47:1107-8.

47. Nault $L R$, Knoke JK: Maize vectors (virus). In: Virus and Viruslike Diseases of Maize in the United States: 1981. Ohio Agricultural Research and Development Center: Southern cooperative series bulletin: 77-84.

48. Dale JL. Isolation of a mechanically transmissible virus from corn in Arkansas. Plant Dis Report. 1964;48:661-3.

49. Redinbaugh MG, Zambrano JL. Control of virus diseases in maize. Adv Virus Res. 2014;90:391-429. https://doi.org/10.1016/B978-0-12-801246-8.00008-1. 
50. Ford RE, Tosic M. New hosts of maize dwarf mosaic virus and sugarcane mosaic virus and a comparative host range study of viruses infecting corn. J Phytopathol. 1972;75(4):315-48. https://doi.org/10.1111/j.1439-0434.1972. tb02627.x.

51. Tosic M, Ford RE, Shukla DD, Jilka J. Differentiation of sugarcane, maize dwarf, Johnsongrass, and sorghum mosaic viruses based on reactions of oat and some sorghum cultivars. Plant Dis. 1990;74(8):549-52. https://doi.org/1 0.1094/PD-74-0549.

52. Stewart LR, Bouchard R, Redinbaugh MG, Meulia T. Complete sequence and development of a full-length infectious clone of an Ohio isolate of maize dwarf mosaic virus (MDMV). Virus Res. 2012;165(2):219-24. https://doi.org/1 0.1016/j.virusres.2012.02.004.

53. Nagyova A, Subr Z. Infectious full-length clones of plant viruses and their use for construction of viral vectors. Acta Virol. 2007;51(4):223-37.

54. Kong P, Steinbiss HH. Complete nucleotide sequence and analysis of the putative polyprotein of maize dwarf mosaic virus genomic RNA (Bulgarian isolate). Arch Virol. 1998;143(9):1791-9. https://doi.org/10.1007/ s007050050417.

55. Petrik K, Sebestyen E, Gell G, Balazs E. Natural insertions within the Nterminal region of the coat protein of maize dwarf mosaic potyvirus (MDMV) have an effect on the RNA stability. Virus Genes. 2010;40(1):135-9. https://doi.org/10.1007/s11262-009-0425-3.

56. Stewart LR, Teplier R, Todd JC, Jones MW, Cassone BJ, Wijeratne S, et al. Viruses in maize and Johnsongrass in southern Ohio. Phytopathology. 2014; 104(12):1360-9. https://doi.org/10.1094/PHYTO-08-13-0221-R.

57. Lindbo JA. TRBO: a high-efficiency tobacco mosaic virus RNA-based overexpression vector. Plant Physiol. 2007;145(4):1232-40. https://doi.org/1 0.1104/pp.107.106377.

58. Louie R. Vascular puncture of maize kernels for the mechanical transmission of maize white line mosaic virus and other viruses of maize. Phytopathology. 1995;85(2):139-43. https://doi.org/10.1094/Phyto-85-139.

59. Redinbaugh MG, Louie R, Ngwira P, Edema R, Gordon DT, Bisaro DM. Transmission of viral RNA and DNA to maize kernels by vascular puncture inoculation. J Virol Methods. 2001;98(2):135-43. https://doi.org/10.1016/501 66-0934(01)00369-X.

60. Chiu W, Niwa Y, Zeng W, Hirano T, Kobayashi H, Sheen J. Engineered GFP as a vital reporter in plants. Curr Biol. 1996;6(3):325-30. https://doi.org/10.1016/ S0960-9822(02)00483-9.

61. Manoli A, Sturaro A, Trevisan S, Quaggiotti S, Nonis A. Evaluation of candidate reference genes for qPCR in maize. J Plant Physiol. 2012;169(8): 807-15. https://doi.org/10.1016/j.jplph.2012.01.019.

\section{Publisher's Note}

Springer Nature remains neutral with regard to jurisdictional claims in published maps and institutional affiliations.

Ready to submit your research? Choose BMC and benefit from:

- fast, convenient online submission

- thorough peer review by experienced researchers in your field

- rapid publication on acceptance

- support for research data, including large and complex data types

- gold Open Access which fosters wider collaboration and increased citations

- maximum visibility for your research: over $100 \mathrm{M}$ website views per year

At $\mathrm{BMC}$, research is always in progress.

Learn more biomedcentral.com/submissions 